NBER WORKING PAPER SERIES

\title{
THE POWERFUL ANTITAKEOVER FORCE OF STAGGERED BOARDS: THEORY, EVIDENCE AND POLICY
}

\author{
Lucian Arye Bebchuk \\ John C. Coates IV \\ Guhan Subramanian \\ Working Paper 8974 \\ http://www.nber.org/papers/w8974 \\ NATIONAL BUREAU OF ECONOMIC RESEARCH \\ 1050 Massachusetts Avenue \\ Cambridge, MA 02138 \\ June 2002
}

For helpful comments we are grateful to Susan A. Chen, Barry Cohen, Jack Jacobs, Marcel Kahan, Louis Kaplow, Eric Robinson, Roberta Romano, Leo Strine and participants in presentations at Harvard Business School, Harvard Law School, the Harvard JD/MBA alumni meeting, the Vanderbilt conference on empirical research in corporate law, the 2001 annual meeting of the American Law and Economics Association, the NYU Law and Business "bridge group," and the University of Tilburg. The views expressed herein are those of the authors and not necessarily those of the National Bureau of Economic Research.

(C) 2002 by Lucian Arye Bebchuk, John C. Coates IV and Guhan Subramanian. All rights reserved. Short sections of text, not to exceed two paragraphs, may be quoted without explicit permission provided that full credit, including $\mathbb{C}$ notice, is given to the source. 
The Powerful Antitakeover Force of Staggered Boards:

Theory, Evidence and Policy

Lucian Arye Bebchuk, John C. Coates IV and Guhan Subramanian

NBER Working Paper No. 8974

June 2002

JEL No. G30, G34, K22

\begin{abstract}
Staggered boards, which a majority of public companies now have, provide a powerful antitakeover defense, stronger than is commonly recognized. They provide antitakeover protection both by (i) forcing any hostile bidder, no matter when it emerges, to wait at least one year to gain control of the board and (ii) requiring such a bidder to win two elections far apart in time rather than a one-time referendum on its offer. Using a new data set of hostile bids in the five-year period 1996-2000, we find that not a single hostile bid won a ballot box victory against an "effective" staggered board (ESB). We also find that an ESB nearly doubled the odds of remaining independent for an average target in our data set, from $34 \%$ to $61 \%$, halved the odds that a first bidder would be successful, from $34 \%$ to $14 \%$, and reduced the odds of a sale to a white knight, from $32 \%$ to $25 \%$. Furthermore, we find that the shareholders of targets that remained independent were made worse off compared with accepting the bid and that ESBs did not provide sufficient countervailing benefits in terms of increased premiums to offset the costs of remaining independent. Overall, we estimate that, in the period studied, ESBs reduced the returns of shareholders of hostile bid targets on the order of 8-10\%. Finally, we show that most staggered boards were adopted before the developments in takeover doctrine that made ESBs such a potent defense.
\end{abstract}

$\begin{array}{lll}\text { Lucian Arye Bebchuk } & \text { John C. Coates IV } & \text { Guhan Subramanian } \\ \text { Harvard Law School } & \text { Harvard Law School } & \text { Harvard Business School } \\ \text { 1557 Massachusetts Avenue } & \text { 1557 Massachusetts Avenue } & \\ \begin{array}{l}\text { Cambridge, MA 02138 } \\ \text { and NBER }\end{array} & \text { Cambridge, MA 02138 } & \\ \text { bebchuk@law.harvard.edu } & & \end{array}$




\section{TABLE OF CONTENTS}

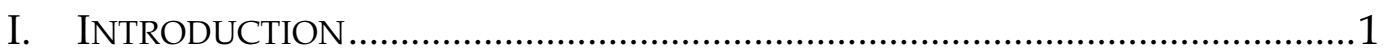

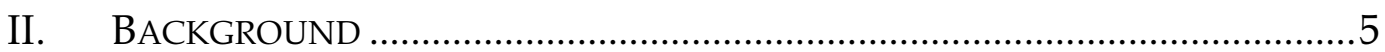

A. The Law of Staggered Boards ...................................................................5

B. The Proliferation of Staggered Boards ................................................ 7

C. Justifications for Staggered Boards .................................................... 8

1. Nontakeover justifications. ............................................................. 8

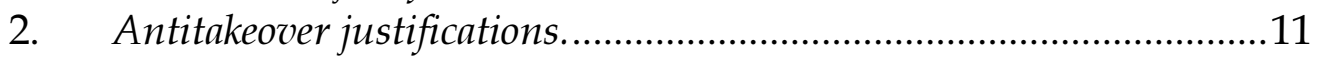

D. The Growing Opposition to Staggered Boards ....................................12

E. Conventional Wisdom on Staggered Boards .......................................14

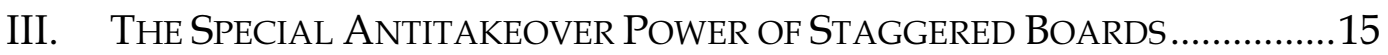

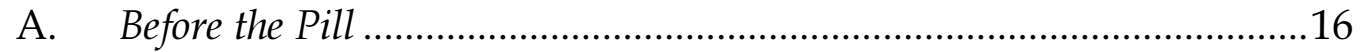

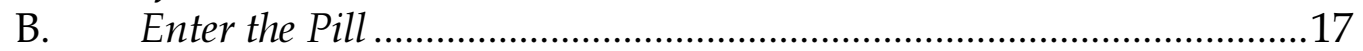

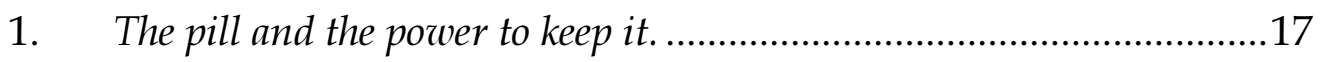

2. The ballot box safety valve. .................................................................2 20

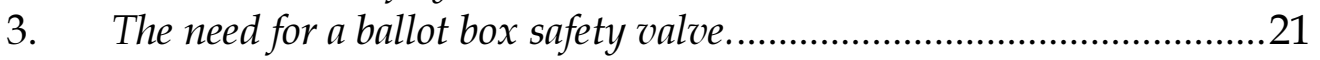

C. Three Types of Targets .................................................................23

1. No minimum term. ............................................................................2 23

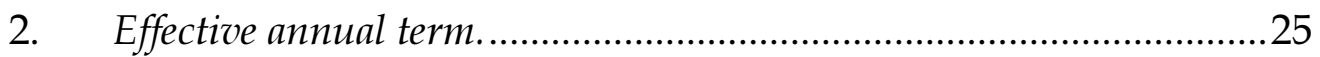

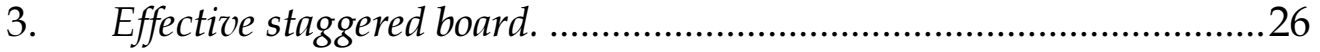

D. The Delay Problem .............................................................................28

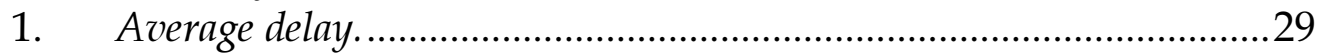

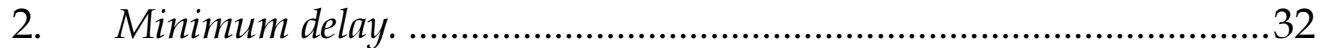

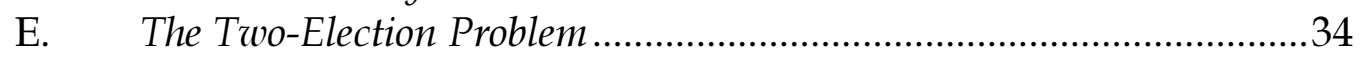

1. The importance of a firm offer for winning a proxy contest.................35

2. The importance of a firm offer against an ESB.................................36

3. The cost of committing to a price ......................................................37

4. Comparison to the one-election case .................................................38

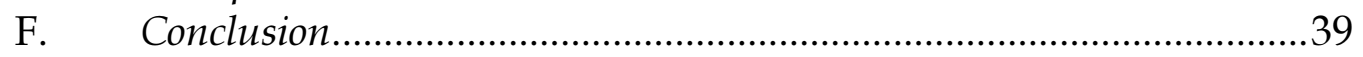

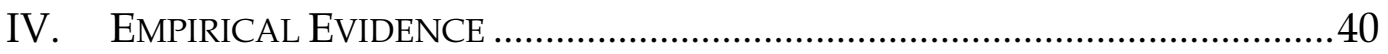

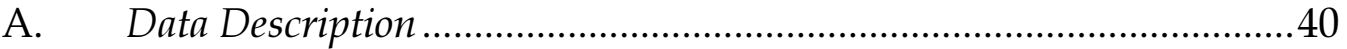

B. Viability of the Ballot Box Mechanism ....................................................43

1. Against ESB targets. ....................................................................4 43

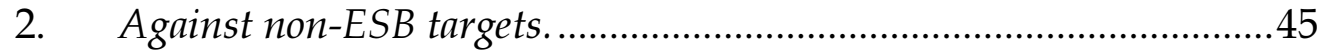

C. Remaining Independent in the Short-run .........................................45

1. General findings............................................................................46

2. Controlling for other parameters. .................................................46

3. Selection problems.......................................................................4 


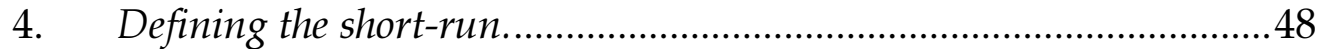

D. Remaining Independent in the Longer-run .........................................49

E. The Cost of Remaining Independent .....................................................50

F. $\quad$ Do ESBs Produce Offsetting Benefits by Increasing Premiums? .........52

G. Overall Effect on Target Shareholder Value ……………………….......53

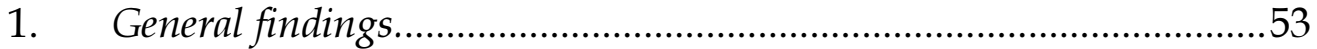

2. Controlling for other parameters. ......................................................54

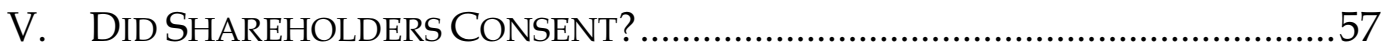

A. A Brief History of Takeovers and Staggered Boards:...............................57

From Inco to Moran to Time .........................................................................57

B. Assessing the Degree of Shareholder Consent .......................................60

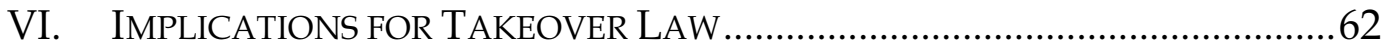

A. Redeeming Pills Following Defeat in One Election.................................62

1. Consistency with fundamental principles of Delaware case law..........63

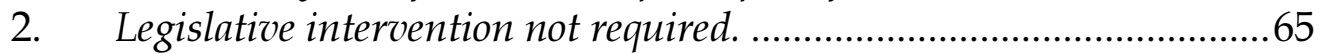

3. Substantial consequences with minimal disruption...............................65

B. The Permissibility of Opt-Out ...........................................................66

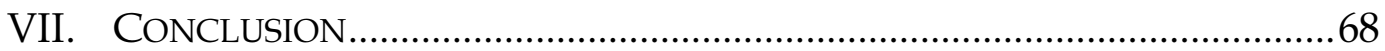

\section{FIGURES \& TABLES}

Figure 1: Staggered Board Incidence by Industry..........................................

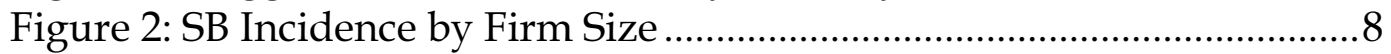

Figure 3: Bid Outcomes in the Short-run......................................................46

Figure 4: Bid Outcomes in the Long-run....................................................49

Figure 5: Staggered Board Incidence by Era.....................................................59

Table 1: Delay Imposed by Various Target Defenses (In Years)...................33

Table 2: Summary Data on Hostile Bid and Target Characteristics .............42

Table 3: Shareholder Returns by Bid Outcome and Target Defenses .........51

Table 4: Overall Effect of ESBs on Target Shareholder Value .......................55 


\section{INTRODUCTION}

Staggered boards (SBs) are an important part of the modern U.S. corporate landscape. In a large sample of major U.S. public companies, 59\% had a staggered board in 1998.1 Among firms going public in the 1990s, the incidence of staggered boards increased from 34\% in 1990 to over $70 \%$ in 2001.2 Despite this large and growing importance in practice, the impact of staggered boards on the market for corporate control has not been adequately recognized by courts, academics, or practitioners.

This Paper analyzes the key role that staggered boards play in the antitakeover protection that U.S. public companies now enjoy. A staggered board, we argue, offers a more powerful antitakeover defense than has previously been recognized. Whereas conventional wisdom holds that a company that becomes a takeover target is unlikely to remain independent, the managers of targets with staggered boards can-and most of the time do-maintain the target's independence.

Our work analyzes how staggered boards make it extremely difficult for a hostile bidder to gain control over the incumbents' objections. Using a new database of hostile bids against U.S. targets in the five-year period from 1996 to 2000, we provide evidence that staggered boards indeed have the powerful antitakeover force suggested by our theory. Finally, we show that the effectiveness of staggered boards reduces returns to target shareholders. The theory and evidence that we put forward have important implications for takeover regulation, and we examine the changes in takeover doctrine that they warrant.

Staggered boards have increased in importance with the appearance and proliferation of poison pills. Takeover law allows managers to maintain a pill and thereby impede a hostile bid, as long as they are in office. As a result, when managers maintain their opposition to a hostile bid, the bidder

1. See Virginia K. Rosenbaum, InVEstor Responsibility Research Center, CORPORATE TAKEOVER DEFENSES $(1993,1998)(n=2,421)$. IRRC includes all firms in the S\&P 1500 plus additional firms "selected primarily on the basis of market capitalization and high institutional ownership levels." See ROSENBAUM (1998), supra, at ix.

2. See John C. Coates IV, Explaining Variation in Takeover Defenses: Blame the Lawyers, 89 CAL. L. REV. 1301, 1353, 1376 (2001) (finding 34\% staggered board incidence in a sample of 160 IPO firms from the period 1991-92, 66\% incidence in a sample of 160 IPO firms from the first nine months of 1998, and 82\% incidence in a sample of 33 IPOs from 1999); Takeover Defenses of Recent U.S. IPOs (chart showing $73 \%$ of IPOs had staggered boards in 2001), at http://www.sharkrepellent.net (last visited Jan. 16, 2002); see also Robert Daines \& Michael Klausner, Do IPO Charters Maximize Firm Value? Antitakeover Protection in IPOs, 17 J.L. ECON. \& ORG. 83, 96 tbl. 2 (finding 44\% staggered board incidence among a sample of 310 firms that went public between 1994 and 1997). 
can obtain control only if it replaces the directors with ones that will redeem the pill. This route of winning control of the board via a ballot box victory provides the safety valve on which takeover law has relied to protect shareholder interests. However, we show that when a target has an effective staggered board (ESB) - a staggered board that is appropriately designed to prevent circumvention - this safety valve is illusory.

There are two reasons why an ESB presents such a serious impediment to a hostile bidder seeking to gain control over the incumbents' objections. First, an ESB substantially increases the delay involved in gaining control of the board and, importantly, establishes a large minimum delay. No matter when a hostile bidder emerges, gaining control of the board would take at least one year, a very long time indeed in the dynamic world of corporate acquisitions. Second, beyond the costs imposed by delay, to overcome an ESB a bidder must win two elections, far apart in time, rather than one up-ordown referendum conducted at a single point in time. We show that the two-election problem is a serious one that, combined with the delay problem, makes an ESB a powerful, even if not insurmountable, antitakeover device. Indeed, we show that an ESB provides managers with stronger protection from a hostile takeover than would an arrangement (not currently permitted under Delaware law) providing directors with guaranteed three-year terms.

After developing our theory of staggered boards, we test it against a new database of hostile bids made against U.S. targets in the five-year period from 1996 to 2000. We find that during this period not a single hostile bidder gained control of the board of an ESB target board through a ballot box victory. The great difficulty that hostile bidders would have in gaining control of the board of a target with an ESB significantly reduces the credibility of the threat to do so, which in turn increases incumbents' power to insist on remaining independent. Specifically, we find that an ESB nearly doubles the likelihood that the average target in our data set will remain independent, from $34 \%$ to $61 \%$; halves the likelihood that the first bidder will be successful, from $34 \%$ to $14 \%$; and reduces the likelihood that a target will be forced to sell to a white knight or other subsequent bidder, from $32 \%$ to $25 \%$.

We also find that the substantial increase in the likelihood of remaining independent produced by ESBs is rather costly for target shareholders. Remaining independent makes shareholders worse off compared with the scenario in which the hostile bid is accepted. Furthermore, we find that ESBs do not provide sufficient countervailing benefits in terms of increased premiums and may even provide no such benefits at all. Overall, we find that ESBs reduced returns on the order of $8-10 \%$ for shareholders of hostile bid targets in the latter half of the 1990s. Some of the statistical tests whose results we report here are presented in greater detail in a more technical 
companion working paper. ${ }^{3}$

These findings lend new significance to shareholder proposals demanding de-staggering of SBs, proposals that have become far more numerous and popular (with shareholders) in recent years.4 More generally, these findings have important implications in the U.S. market for corporate control and the broader business landscape. Staggered boards play a key role in determining the extent to which managers of U.S. companies are vulnerable to a takeover threat. The theoretical arguments and empirical evidence presented here suggest that ESBs substantially increase the insulation of incumbents from takeovers and have the potential to reduce shareholder wealth.

After analyzing the antitakeover consequences of staggered boards, we examine how we have arrived at this state of affairs. We compare the evolution of takeover law with the timing of staggered board incidence. We show that most companies that now have staggered boards adopted them before shareholders could have been fully aware of the powerful antitakeover force that was accorded to them by subsequent developments in takeover law. Specifically, shareholders that had approved staggered boards prior to 1990 found themselves in the 1990s stuck with an arrangement whose full antitakeover power they could not have earlier anticipated. In the 1990s, shareholders began to comprehend the full antitakeover force of staggered boards and, led by activist institutional investors, began voting against proposals to adopt new staggered boards and for precatory (nonbinding) proposals to rescind existing ones.5 For most companies, however, this shareholder activism amounted to "too little, too late," because the majority of large companies had already adopted staggered boards, which shareholders do not have the power to undo.

Our conclusions concerning the special antitakeover power of staggered boards call for a reconsideration of existing takeover law. Courts have sought to strike a balance between the goals of protecting shareholders from

3. See Lucian Arye Bebchuk, John C. Coates IV \& Guhan Subramanian, The Effects of Takeover Defenses (working paper, 2002).

4. See Jason D. Montgomery, Classified Boards, Corporate Governance Services, Investor Responsibility Research Center (Mar. 3, 1998); Record Support for Destaggered Boards Highlights Shareholder Proposal Results, Corporate Governance Highlights, Investor Responsibility Research Center (June 18, 1998), at 97.

5. New staggered boards emerged throughout the 1990s, however, in IPOs. See Coates, supra note 2, at 1377; Daines \& Klausner, supra note 2, at 96 tbl. 2. Shareholders have been willing to buy shares from companies that have staggered boards in their initial charter. In those cases, the initial price could reflect the costs to shareholders of staggered boards, although it is also possible that investors in IPOs are still not fully aware of the antitakeover potential of staggered boards. See infra Part II.D. 
threats that some hostile offers might present and preventing managers from entrenching themselves. Under the well-known Unocal test, managers can use defensive tactics but only to an extent that is "reasonable in relation to the threat posed." 6 Allowing managers to maintain a pill as long as they are in office, courts have believed, is a proportionate measure because of the availability of the proxy contest safety valve. Our analysis shows, however, that this safety valve on which courts have relied is largely illusory against companies with an ESB.

Accordingly, when a target has an ESB (which is approximately half the time), courts applying the proportionality test should not permit managers to maintain a pill after they lose one election conducted over an acquisition offer. Allowing managers to maintain a pill after what was essentially a referendum on the offer would be a disproportionate and substantially entrenching measure. Therefore, we argue, preventing the use of a pill-ESB combination following defeat in one election would be consistent with the proportionality test put forward by Unocal and subsequently by Moran. In addition, our approach would preserve the nontakeover benefits that are often cited to justify staggered boards-board stability and board independence- while ensuring that staggered boards are not unduly used to defeat offers that enjoy shareholder support.

The remainder of this Paper proceeds as follows. Part II provides the necessary background: an account of the widespread use of staggered boards, the justifications offered for them, and the rising shareholder resistance to them. Part III offers our theory of staggered boards and demonstrates why, at a theoretical level, ESBs are very powerful against hostile takeover bids, more powerful than has been recognized. Part IV provides empirical evidence that supports this theory. Part V examines how this state of affairs came about and documents that the large majority of ESBs had been adopted before shareholders could have recognized the antitakeover significance that ESBs would obtain as a result of subsequent judicial and legislative developments. Part VI discusses the policy implications of our analysis and makes recommendations that would improve the efficiency and legitimacy of takeover doctrine. Part VII concludes.

6. Unocal Corp. v. Mesa Petroleum Co., 493 A.2d 946, 955 (Del. 1985). 


\section{BACKGROUND}

\section{A. The Law of Staggered Boards}

The default law in all states requires that all directors stand for election at each annual shareholder meeting.7 However, all states provide an exemption from this requirement if the board is staggered.8 In a company with a staggered board, directors are grouped into classes (typically three), with each class elected at successive annual meetings. For example, a board with twelve directors might be grouped into three classes, with four directors standing at the 2001 annual meeting, four more directors standing for reelection in 2002, and the remaining four directors standing for reelection in 2003.9 With three classes, directors in each class would be elected to threeyear terms.

Thirty-nine jurisdictions, including Delaware and California, permit a maximum of three classes.10 New York permits as many as four classes of directors,11 and Arizona allows three "or to the extent not inconsistent with cumulative voting rights, more." 12 Ten other states have not addressed this issue.13

7. See, e.g., Del. Code ANN. tit. 8, § 211(b) (2000); Model Bus. Corp. ACT § 8.03(d) (1999). Moreover, if the corporation does not hold an annual shareholder meeting within thirteen months (in Delaware) or fifteen months (under the Revised Model Business Corporation Act, or the RMBCA) of the last meeting, a court may order an annual meeting on the petition of any stockholder or director. See Del. CodE AnN. tit. 8, § 211(c) (2000); MODEL BUS. CORP. ACT § 7.03(a)(1) (1999).

8. See Grant A. GARTMAN \& JACK D. IsAaCS, InVESTOR ResPONSIBILITY RESEARCH Center, Corporate Governance State by State: A Guide to Selected Statutes (1998).

9. While Delaware does not require the classes to be roughly equal in number, the RMBCA does. Compare Del. CODE ANN. tit. 8, § 141(d) (2000), with MODEL BUS. CORP. ACT § 8.06 (1999). However, regardless of whether required or not by statute, most companies that install a staggered board impose this requirement on themselves, perhaps because by doing so they maximize the antitakeover protection of the SB. See, e.g., Bestfoods Restated Certificate of Incorporation $§ 11(8)$ (requiring the same number of directors in each class, "as nearly as may be possible"). But see ARV Assisted Living Bylaws $\S 3.3$ (allowing the board to determine without restriction the number of directors in each class).

10. See Richard H. Koppes, Lyle G. Ganske \& Charles T. Haag, Corporate Governance Out of Focus: The Debate Over Classified Boards, 54 Bus. LAW. 1023, 1029 n.21 (1999).

11. N.Y. BUS. CORP. LAW § 704(a) (McKinney 2001).

12. ARIZ. ReV. StAT. ANN. § 10-806 (West 1996).

13. See Koppes, Ganske \& Haag, supra note 10, at 1029 n.21. 
Delaware allows an SB to be specified either in the charter or in the bylaws, 14 while the Revised Model Business Corporation Act (RMBCA) only provides for an SB to be specified in the charter.15 In all states, installing an $\mathrm{SB}$ through charter amendment requires both shareholder approval and board approval,16 while installing an SB in the bylaws requires either shareholder approval or board approval.17 Conversely, dismantling an SB that is in the charter requires both a shareholder vote and a board vote, while dismantling an SB in the bylaws can be done either through shareholder vote or through board vote. Thus, while SBs have the same (direct) effect whether installed through the charter or through the bylaws, SBs in the bylaws are generally much easier to dismantle.18

If an SB is installed in the charter, directors may only be removed for cause, and shareholders may not "pack the board" by increasing the number of directors and filling the vacancies created, then we characterize the SB as an "effective staggered board" (ESB) - one that cannot be dismantled by a hostile bidder without first winning control of the board. ${ }^{19}$ As we shall see below, the distinction between an SB and an ESB is irrelevant for two of the arguments put forward to explain SBs-board stability and board

14. See Del. Code ANN. tit. 8, § 141(d) (2000).

15. See MOdEL Bus. CORP. ACT $\S 8.06$ (1999).

16. See, e.g., Del. Code AnN. tit. 8, § 242(b)(1)-(2); Model Bus. Corp. ACt § 10.03 (1999) (requiring board approval and shareholder approval for all but minor changes to the charter).

17. Delaware requires that the charter expressly provide for board authority to amend the bylaws, while the RMBCA reverses this default rule, allowing the board to amend the bylaws unless otherwise specified in the charter. Compare DEL. CODE ANN. tit. 8, § 109(a) (2000), with MODEL BUS. CORP. ACT § 10.20 (1999). Both corporate codes and all states allow shareholders to amend the bylaws. See DEL. CODE ANN. tit. 8, § 109(a) (2000); MODEL BUS. CORP. ACT § 10.20(b) (1999).

18. A staggered board specified in the bylaws might be as difficult to dismantle as a staggered board specified in the charter if the charter specifies that the board must approve any modifications to board structure, effectively making the staggered board provision in the bylaws equivalent to a charter provision. See, e.g., Articles of Incorporation and By-Laws of Quality Dining, Inc. (requiring board approval for "any elimination or modification of the groups or terms of office of the Directors as the ByLaws then in effect may provide"). In addition, a supermajority voting requirement for shareholder bylaw amendments may make a staggered board in the bylaws equivalent to a charter provision, which can be such a hurdle to dismantling as to be practically akin to an outright ban. See, e.g., Circon By-Laws (requiring a two-thirds vote for any shareholder amendments to the bylaws); see also infra note 99 (discussing the effect of a supermajority amendment requirement in preserving a staggered board installed in the bylaws of the takeover bid for Circon).

19. See Coates, supra note 2. 
independence-but becomes highly relevant for the third (and we believe most important) reason for SBs, to make hostile takeovers more difficult. We therefore make this distinction between SBs and ESBs throughout the remainder of this Paper.

\section{B. The Proliferation of Staggered Boards}

Though staggered boards have been a part of the corporate law landscape for decades,20 they gained popularity during the 1980s takeover wave. Today, among a sample of 2,421 large public U.S. companies, $59 \%$ have staggered boards.21 In addition, there was a dramatic increase in staggered board incidence among companies going public in 1991-92 (34\%) versus 1999-2000 (82\%).22 The IPO statistics suggest that, barring any major shifts in the legal or political environment, staggered board incidence will only increase further among major U.S. corporations in the years to come.

Figure 1 shows that SBs are represented broadly across industries:23

Figure 1: Staggered Board Incidence by Industry

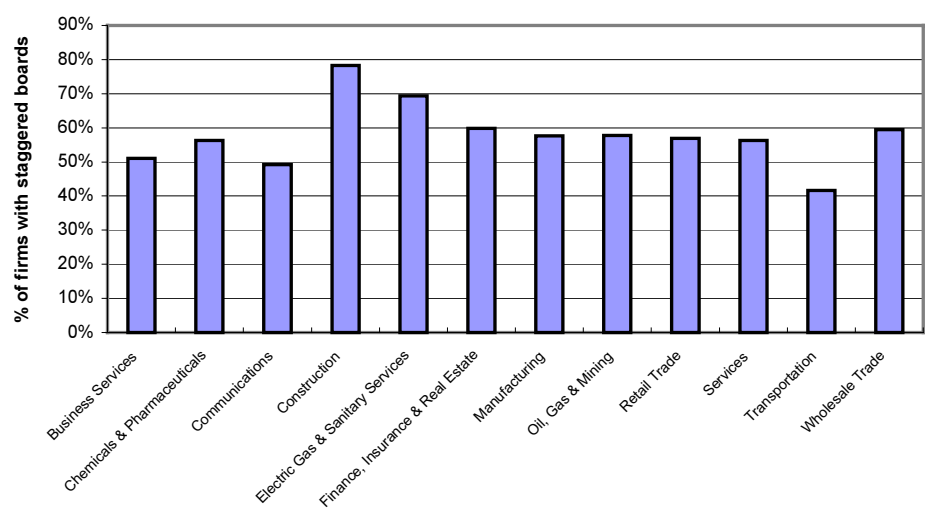

20. Among the approximately 2500 companies in the Investor Responsibility Research Center (IRRC) database, the first staggered board appeared in the company now known as Equifax in 1920. See sources cites supra note 1.

21. The sample comes from the 1993 and 1998 volumes of the IRRC Corporate Takeover Defenses databooks, which include all firms in the S\&P 1500 plus additional firms "selected primarily on the basis of market capitalization and high institutional ownership." ROSENBAUM, supra note 1 , at ix.

22. See Coates, supra note 2, at 1353, 1376.

23. The construction of these industry classifications comes from George P. Baker \& Guhan Subramanian, The Global Market for Corporate Control (unpublished data, on file with the authors). 
Figure 1 shows no pronounced industry effect for staggered board incidence. In all industries except Transportation and Communications, staggered boards appear in the majority of firms, and in two industriesConstruction and Electric, Gas, and Sanitary Services-staggered board incidence is $70 \%$ and higher.

Figure 2 shows staggered board incidence by firm size:

Figure 2: SB Incidence by Firm Size

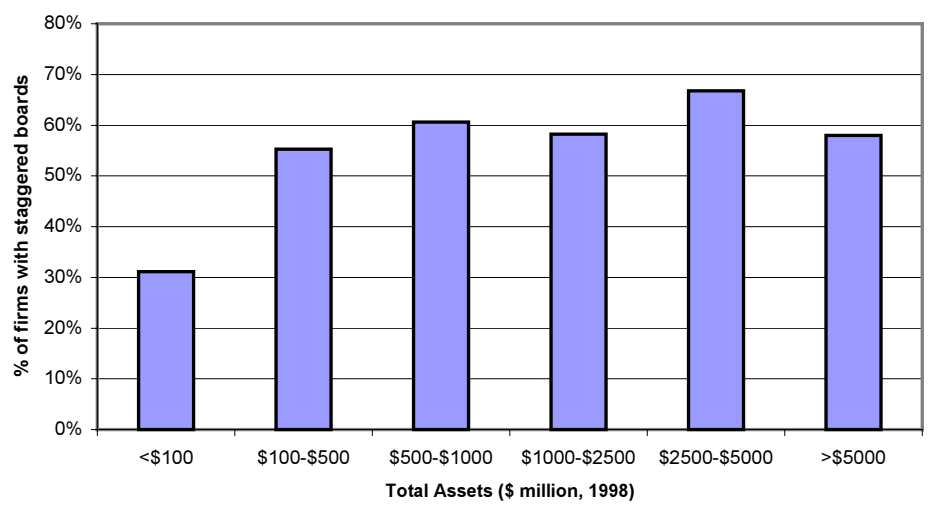

Figure 2 shows that staggered boards are well represented across companies of varying sizes. The only statistically significant difference occurs at the low-end of the spectrum, where staggered boards are slightly under-represented. This finding is consistent with evidence from one of us that staggered boards were less common at smaller IPO firms in the 1990s, controlling for insider ownership.24 One possible explanation is that smaller firms may be advised by lawyers with less takeover experience, who are less likely to install staggered boards. 25

\section{Justifications for Staggered Boards}

\section{Nontakeover justifications.}

Two nontakeover-related justifications have been put forward to justify staggered boards. First, they facilitate the independence of outside directors.26 Independent directors, goes this argument, will be less influenced by executives if they have a term of three years rather than one year. Second, they reduce annual turnover on the board, thereby promoting board

24. See Coates, supra note 2 , at 1371 , tbl. 6 .

25. See id. at 1360-64 (finding that outside counsel are often responsible for choosing takeover defenses).

26. See, e.g., Koppes, Ganske \& Haag, supra note 10, at 1053-54. 
stability.27 It is generally good, goes the argument, to always have some experienced and seasoned directors, who have the perspective that only time on the board can provide. If the board were not staggered, there is in theory some chance that all board members in a given year will be rookies. A staggered board prevents this outcome by ensuring that at most one-third of the board members will be new. 28

However, a staggered board imposed through the charter is an unnecessarily blunt instrument to achieve these two benefits. On board independence, a bylaw establishing a staggered board would be sufficient to provide independent directors autonomy from management so that they could effectively monitor. Because officers cannot amend the bylaws without approval of a majority of the whole board, a majority-independent board would not be de-staggered against the will of the independent directors.29 A bylaw would thus accomplish the independence goal without, as will be made clear below, in any way impeding a hostile bidder.30

27. See id. at 1051-52.

28. See, e.g., Avant Corporation Proxy Statement, Proposal No. 2 (April 7, 1998) (advocating a staggered board because classification "will help lend continuity and stability to the management of the Company"); Cornell Corrections Proxy Statement (March 9, 1998) (advocating staggered board "to promote continuity and stability"); Rental Service Corp. Proxy Statement, Proposal No. 2 (March 30, 1998) (same).

29. Even at the minority of public companies that lack a majority of independent directors, it would be controversial and reputationally costly for officers to de-stagger the board against the will of the independent directors. An independent director would not expect that, if he or she were to display independence, insiders would amend the bylaws to cut short the term of the independent director.

30. Although the RMBCA requires a staggered board to be in the charter, most states do not seem to follow the RMBCA on this point. In addition, Delaware permits a staggered board to be specified in either the charter or the bylaws, and $50 \%$ of all public companies are incorporated in Delaware. See Guhan Subramanian, The Influence of Antitakeover Statutes on Incorporation Choice in the 1990s: Evidence on the "Race" Debate and Antitakeover Overreaching, U. PA. L. REV. (forthcoming 2002) (manuscript at 17, fig. 2, on file with authors); Lucian Arye Bebchuk \& Alma Cohen, Firms' Decisions Where to Incorporate, (Harvard Olin Discussion Paper No. 352, 2002), available at http://papers.ssrn.com/abstract=296492; Lucian Arye Bebchuk, Alma Cohen, and Allen Ferrell, Does the Evidence favor State Competition in Corporate Law? CAL. L. REV. (forthcoming 2002) (manuscript at Table 2). In the small number of states which require a staggered board to be specified in the charter, we believe that both board stability and board independence could be achieved through a convention or policy (e.g., that the slate should be two-thirds incumbent directors), which would avoid the antitakeover consequences of a staggered board specified in the charter. Alternatively, a staggered board could be installed in the charter but shareholders could specifically be given the power to remove directors without cause, as suggested by Koppes, Ganske \& Haag, supra note 10. See infra Part III.C (discussing ways to avoid the antitakeover power of 
Similarly, on board stability, a staggered board bylaw would achieve the goal of preventing excessive turnover, and even a company without a staggered board could have a convention or policy requiring that annual slates include at least two-thirds incumbent directors in the ordinary course of business. Such a policy or bylaw would be followed in the normal course of events.31 As an empirical matter, even in companies that do not have any policy or rule against replacing more than one third of the board in any given year, such high turnover rarely, if ever, happens outside the change of control context.32 In the normal course of business, most of the candidates running on the insiders' slate are usually those who are already serving on the board. Thus a convention, policy, or bylaw should provide the desired board independence and board stability in the normal course of events in a more focused way than a staggered board.

Of course, in one situation a convention, policy, or bylaw would be insufficient-in the case of a hostile change of control. When a buyer acquires a controlling interest, it would be natural for it to replace the directors with a new slate of directors, assuming that it were not stopped by the charter. Thus, alternatives that stop short of a charter amendment would not likely prevail in the case of a hostile takeover.

But a desire for board stability no longer makes sense in the case of a hostile change of control. The argument for continuity presupposes that there is some team working largely in harmony, and that such a team would benefit from retaining a majority of experienced members from whom new members could and would be willing to learn. But in the case of a hostile takeover, old and new directors are not going to form a harmonious team. 33 In such a case, board stability indeed might be quite harmful. In fact, arguments for board stability, through "dead hand" and "no hand" pills,

SBs).

31. Observe, for example, that many companies (such as Boeing and GE) follow policies mandating a certain retirement age for the CEO, even in companies with successful and powerful CEOs. It would seem that to retire a CEO at 65 would require a stronger commitment device than is needed to retire only part of the directors, yet we know of no such policies that are written in to the bylaws or charter.

32. See, e.g., Rental Services Corp. Proxy Statement, Proposal No. 2 (March 30, 1998) (acknowledging that "the Company has not yet experienced problems with respect to continuity," but nevertheless advocating a staggered board "to provide continuity and stability to the Company's management").

33. For a somewhat humorous illustration of this point, see Brian Hall, Christopher J. Rose \& Guhan Subramanian, Circon (A) (Harvard Business School Case Study N9801-403) (describing how dissident director General Victor Krulak reportedly asks fellow dissident Charles Elson to call him by his nickname, Brute, but then introduces himself to the incumbent directors with: "This is General Krulak."). 
have already been rejected by the Delaware Chancery Court34 and the Delaware Supreme Court.35 Thus charter-based staggered boards are overencompassing because they provide board stability when business justification and support in the Delaware case law are both at their weakest.36

\section{Antitakeover justifications.}

The third reason often given to explain staggered boards is that they make hostile takeovers more difficult.37 For reasons we discuss in Part V, this justification may have been unintended when staggered boards first appeared, but the key point is that the interaction between a staggered board and a poison pill puts up a potent defense against a hostile bidder. A pill provides relatively weak takeover protection if the target is vulnerable to a rapid proxy fight, because the target's board can redeem the pill at any time; a staggered board without a pill is likewise ineffective against a bid, given the unlikelihood that target directors will continue to resist if a bidder has acquired a majority of the target's stock. In combination with an effective staggered board, however, a pill provides significant antitakeover protection: the pill blocks any stock acquisition beyond the trigger level, and the

34. See Carmody v. Toll Bros., Inc. 723 A.2d 1180 (Del. 1998) (ruling that claim challenging dead hand pill survives motion to dismiss).

35. See Quickturn Design Sys., Inc. v. Shapiro, 721 A.2d 1281 (Del. 1998) (invalidating slow hand pill); see also Bank of New York v. Irving Bank, 528 N.Y.S.2d 482, 485-86 (N.Y. Sup. Ct. 1988) (invalidating dead hand pill under New York law).

36. See, e.g., Topps Co. Proxy Statement, Proposal No. 4 (May 28, 1998) (shareholder proposal to remove a staggered board because "in the unlikely event that stockholders vote to replace all directors, this decision would express stockholder dissatisfaction with the incumbent directors and reflect the need for change"); Bausch \& Lomb Proxy Statement, Shareholder Proposal No. 2 (Mar. 19, 1998) (same).

37. See, e.g., Eastman Kodak Proxy Statement (Mar. 19, 1998) (arguing, in the fifth of five points in favor of a staggered board, that it "inhibits unfriendly take-over attempts"); Rental Service Corp. Proxy Statement, Proposal No. 2 (Mar. 30, 1998) (acknowledging that the installation of a staggered board "may have potential antitakeover effects"). Many management statements against staggered board rescission, or in favor of new staggered boards, argue that this antitakeover effect gives management greater bargaining power. See, e.g., Bausch \& Lomb Proxy Statement, Shareholder Proposal No. 2 (Mar. 19, 1998) ("The classified board does not preclude unsolicited acquisition proposals but, by eliminating the threat of imminent removal, puts the incumbent Board in a position to act to maximize value to all shareholders."); Bristol Myers Squibb Proxy Statement, Proposal No. 3 (Mar. 16, 1998) ("One benefit derived from that situation is an enhancement of management's ability to negotiate in the best interest of all stockholders with a person seeking to gain control of the corporation."). 
staggered board forces the bidder to go through two proxy contests in order to gain control of the board and redeem the pill.38

Statistics on staggered board incidence are consistent with the view that staggered boards are at least partly motivated by antitakeover considerations. As noted in Part II.B, staggered boards are relatively less common among smaller firms, where ownership is typically more concentrated and hostile takeovers may be more difficult or impossible (if insiders own a controlling stake). Furthermore, staggered boards were far less common before the 1980s takeover wave,39 even though the board stability and board independence arguments (presumably) applied with equal force before 1980 as after.40

\section{The Growing Opposition to Staggered Boards}

While SBs are commonplace among all types of U.S. public companies, very few SBs have been proposed by management and approved by shareholders since 1990. The reason is simple: Shareholders have stopped voting in favor of new staggered boards. The emergence of shareholder activism in the early 1990s, combined with important changes in the Delaware case law around the same time, ${ }^{41}$ made institutional investors acutely aware of the potential for managerial entrenchment behind an $\mathrm{SB} /$ pill combination. As a result, their support for staggered boards largely vanished, and companies that did not already have their staggered boards in place by 1990 had missed the party. Among companies covered by the IRRC, management proposals to classify boards dropped from 88 proposals in 1986 to just ten proposals in 2000.42 Of these ten, only four involved companies in which management did not own a controlling stake; among

38. See, e.g., Federated Department Stores Proxy Statement, Proposal No. 3 (Apr. 16, 1998) ("The Company's outside advisors have informed the Company that they continue to believe that classified directorate terms are important to ensure the efficacy of stockholder rights plans.").

39. See infra Figure 5.

40. Note also that staggered boards are much less common in the United Kingdom, where they are less useful as antitakeover devices without the accompanying jurisprudence in support of the poison pill. Again, the board stability and board independence arguments would seem to apply with equal force in the United Kingdom as in the United States, yet staggered board incidence in the United Kingdom is much lower.

41. See infra Part V.

42. See Michael Klausner, Institutional Shareholders' Split Personality on Corporate Governance: Active in Proxies, Passive in IPOs 3 tbl. 1 (Stanford Law School, Working Paper No. 255, November 2001). 
these four, only one was successful. ${ }^{43}$

In fact, activist shareholders began trying to turn back the tide by proposing resolutions to de-stagger boards. These proposals, along with proposals to redeem pills, were increasingly popular with shareholders during the 1990s,44 although they have no binding effect and therefore have been routinely ignored by managers. The average shareholder vote in favor of proposals to de-stagger the board increased from $16.4 \%$ in 1987 to $52.7 \%$ in 2000.45 One of us in other work has speculated that these proposals would garner even greater support were they binding on boards. 46

The experience at Bausch \& Lomb is typical. In 1997, shareholder activist William Steiner from the Investor Rights Association of America sponsored a proposal urging the board to de-stagger itself:

[T] he Company's classified Board of Directors maintains the incumbency of the current Board and therefore of current management, which in turn limits management's accountability to stockholders. ... I believe that [de-staggering the board] is one of the best methods available to the stockholder to insure that the Company will be managed in a manner that is in the best interests of the stockholders.47

The Bausch \& Lomb board of directors argued against the proposal:

The Board stated in the proxy statement relating to that meeting [approving the staggered board] its belief that the amendment would reduce the vulnerability of the Company to certain potentially abusive takeover tactics and encourage potential acquirers to negotiate with the Board. The Board also stated its belief that the amendment assures continuity and stability of the Company's management and policies, since a majority of the directors at any given time have prior experience as directors of the Company.

In the opinion of the Board, the above reasons continue to be valid and the staggered Board remains in the best interests of the shareholders. ... The staggered board does not preclude unsolicited acquisition proposals but, by eliminating the threat of imminent

43. See id. at 4 .

44. See John C. Coates IV, Measuring the Domain of Mediating Hierarchy: How Contestable Are U.S. Public Corporations?, 24 J. CORP. L. 837, 861 tbl. 5 (1999) (measuring the steady increase in shareholder votes for precatory resolutions to redeem the poison pill and de-stagger the board).

45. See Klausner, supra note 42, at 3 tbl. 1.

46. See Lucian Arye Bebchuk \& Allen Ferrell, A New Approach to Takeover Law and Regulatory Competition, 87 VA. L. REV. 111, 127-128 (2001).

47. Written Statement of William Steiner, Bausch \& Lomb Proxy Statement, Shareholder Proposal No. 2 (Dec. 28, 1996). 
removal, puts the incumbent Board in a position to act to maximize value to all shareholders. In addition, the Board does not believe that directors elected for staggered terms are any less accountable to shareholders than they would be if elected annually, since the same standards of performance apply regardless of the term of service. 48

The Steiner proposal received 62\% approval from Bausch \& Lomb shareholders, yet the company continued to maintain a staggered board. ${ }^{49}$

\section{E. Conventional Wisdom on Staggered Boards}

Thus far in this Part we have argued that the motivation for installing staggered boards, as well as the motivation for shareholder activism against them, comes from their potential antitakeover consequences. These antitakeover consequences are the focus of this Paper; our thesis is that they are greater than has previously been recognized. Although most scholars and practitioners recognize that staggered boards have some antitakeover effect, the conventional wisdom is that the magnitude of this effect is not very large.

We interviewed fifteen senior partners from major law firms in New York City and Wilmington, Delaware and found consensus around the view that targets, once in play, will generally trade to either the initial bidder or to a white knight.50 When presenting drafts of this Paper, we also surveyed M\&A practitioners and corporate law academics to get their quantitative assessment of the impact of staggered boards on bid outcomes.51 Among

48. See Written Statement of Bausch \& Lomb Board of Directors, Bausch \& Lomb Proxy Statement, Shareholder Proposal No. 2 (Dec. 28, 1996).

49. See Bausch \& Lomb Votes by Shareholders Go Against Management, WALL ST. J. (April 30, 1997) at B7 (reporting 28 million shares voted in favor of one-year terms, 17 million shares voted opposed, and 0.3 million abstentions).

50. Selected comments are illustrative: "Once somebody starts, and commits to the deal, the ego of the CEO, etc., generally drive it to completion. . . . Like everything else, it's the price that determines whether or not the deal is successful." "Given that the target is put into play, it's likely to go. If a bidder is willing to pay, it will succeed. If it is not willing to pay, someone else will come along." This conventional wisdom seems to hold among bankers ("Bankers will come to you and say, 'Life will now change for you-either you will be bought by [the hostile bidder] or you will be bought by someone else.'") and gets transmitted to clients ("Our investment bankers and everybody told us that once a hostile bid is made, $80 \%$ are successful. So we assumed ... that we were going to be taken over one way or another.").

51. Before the presentation, each participant was asked to answer two questions: (1) what is the overall likelihood of a target remaining independent once a hostile bid has been made; and (2) what is the likelihood of a target remaining independent once a hostile bid has been made if the target has an effective (non-evadable) staggered board? 
M\&A lawyers, the mean estimate for likelihood of remaining independent increased by only $5 \%$ when the target had an effective staggered board.52 Among corporate law academics, the mean estimate for the likelihood of remaining independent increased by $9 \% .53$ As we will show in Part IV, the actual effect is several times larger than these estimates. The business press also holds the view that the presence or absence of a staggered board is relatively unimportant.54

However, it is important to note that our main thesis in this Paper does not depend on the above account of the conventional view. We plan to study more rigorously in other work the extent to which this view exists, and, if widespread, what are the sources of the misperception that sophisticated parties seem to have adopted. In this Paper, however, we focus on showing that staggered boards have a powerful antitakeover effect and on identifying the sources of this effect. This analysis and its conclusions do not depend on whether market participants have or have not fully recognized the significance of staggered boards.

\section{THE SPECIAL ANTITAKEOVER POWER OF STAGGERED BOARDS}

In Part II we showed that staggered boards are an important part of the corporate landscape today. We also argued that the standard non-takeover related justifications for staggered boards (board independence and board stability) are relatively weak, and that the empirical evidence on staggered board incidence is most consistent with the view that staggered boards are motivated primarily by antitakeover reasons. In this Part we develop a theory demonstrating that staggered boards are in fact extremely potent as an antitakeover device. In the next Part we provide large-sample empirical evidence in support of this theory.

Each respondent individually wrote his or her response on a note card without discussion. Respondents only identified whether they were an academic or a practitioner. Responses were tabulated anonymously and reported back to the group. Respondents did not know they would be asked to answer these questions when they arrived at the seminar.

52. The mean estimate among practitioners increased from $12 \%$ (independence rate against bids for targets overall) to $17 \%$.

53. The mean estimate among corporate law academics increased from $38 \%$ to $47 \%$.

54. See, e.g., Avrum D. Lank, Hostile Takeover Attempts Force Investors to Make Tough Decisions, MiLWAUKEE J. SENTINEL, Jan. 11, 1998, at Business 2 ("Only infrequently does a company put in play by a hostile takeover offer emerge intact."); Anita Raghavan, In Europe, a New Storm over Takeover Rules, WALL ST. J., Dec. 5, 2000, at A21 ("In the case of unsolicited, hostile offers, most boards ultimately cave in to shareholder pressure and dismantle their antitakeover defenses."). 
Parts III.A and III.B provide a brief chronology of the important Delaware case law, noting the dramatic changes brought about by the arrival of the poison pill in 1984. Part III.C summarizes the existing regime and identifies the three types of targets that now exist. Part III.D analyzes the "delay problem" and demonstrates that ESBs impose even more delay on bidders than alternative regimes, currently not permitted, which would allow biennial or triennial election of a single class of directors. Part III.E focuses on the "two-election problem" to show that the potency of an ESB against a hostile bid goes beyond delay. We conclude from this analysis that the ballot box safety valve, which Delaware courts relied on so heavily in the development of their takeover jurisprudence over the past two decades, is rendered virtually ineffective against an ESB target.

\section{A. Before the Pill}

Even before the pill, a staggered board was considered to be a defense, though a rather weak one.55 Basically a staggered board would delay a bidder's ability to take control of the board until two annual elections were over, even if the bidder owned a majority of the shares through a successful tender offer. This outcome would make the hostile acquisition of a control block less desirable, because capturing the benefits of control would be delayed for as long as two years.

The pre-pill staggered board was nevertheless weak, for several reasons. First, a staggered board did not prevent a bidder from acquiring a controlling block and creating a situation in which, albeit with some delay, it would definitely gain control. Thus the staggered board did not impede the acquisition of a controlling block; it only delayed the ability of the buyer to exercise its voting power. Put differently, a bidder who needed to know (say, for strategic planning purposes) whether it would be able to gain control of Company X could find out the answer without delay. At most, the realization of that control would be delayed, but it would be inevitable.

Second, it was generally believed that, if a bidder were to acquire a majority of the shares of a company with a staggered board, it would not in fact take the buyer two elections to gain control of the board because the board could be expected to resign.56 There were two reasons for this

55. See Robert Charles Clark, CorPORATE LAW 576 (1986) (listing SBs as takeover defenses but characterizing them as fairly weak); Ronald J. Gilson, A Structural Approach to Corporations: The Case Against Defensive Tactics in Tender Offers, 33 STAN. L. REV. 819 (1981).

56. See CLARK, supra note 55, at 576 ("In practice, of course, the incumbent directors would often find it in their interest to come to terms with the new controlling shareholder."); Gilson, supra note 55. 
prediction. First, the board would have little legitimacy continuing to serve when the majority shareholder clearly did not wish it to stay. Staying would likely hurt the personal reputations of the board members. Second, this reputational cost would come with little benefit because eventually losing independence was a certainty and because an incumbent board could accomplish little against the will of a controlling shareholder. At best, incumbent directors could hang on for a bit longer, delaying the ability of a majority shareholder to use freely its impending control position. All of this made mass resignation a highly likely scenario.

\section{B. Enter the Pill}

The pill dramatically changed how quickly a board could be replaced by shareholders. In the era of the pill, a potential buyer would need an election not to use the voting power of the block it had already acquired, but rather to buy the block in the first place. Pills made staggered boards important.

\section{The pill and the power to keep it.}

Poison pills57 consist of stock warrants or rights that allow the holder to buy an acquirer's stock (a so-called "flip over" provision), the target's stock (a "flip in" provision), or both at a substantial discount from the market price. These rights only become exercisable in the event that a shareholder (the "acquiring person") buys more than a certain percentage of the target's stock (typically 10 or 15\%) without the target board's approval.58 These rights are explicitly not exercisable by the acquiring person, so the resulting dilution in his voting power and economic stake may make the acquisition of the target through market purchases too expensive to pursue. Although in theory a hostile bidder could "break through" a poison pill by triggering it, suffering the resulting dilution, and continuing to buy shares, no bidder has ever done so in our fifteen-plus years of experience with the pill.59 In

57. Throughout, "pill" or "poison pill" means a standard poison pill, which permits redemption by the target board, however constituted, at any time. We treat separately pills that attempt to interfere with proxy fights and/or a target board's ability to redeem the pill (so-called "dead hand" or "slow hand" pills).

58. For a description of the common features of a poison pill, see Wachtell, Lipton, Rosen \& Katz, The Share Purchase Rights Plan, reprinted in RONALD J. GILSON \& BERNARD S. BLACK, THE LAW AND FINANCE OF CORPORATE ACQUISITIONS 10-18 (2d ed. Supp. 1999). For a description of how a pill is implemented, see John C. Coates IV, Takeover Defenses in the Shadow of the Pill: A Critique of the Scientific Evidence, 79 TEX. L. REV. 271, 287 n.62 (2000).

59. Sir James Goldsmith threatened to trigger Crown Zellerbach's pill in his hostile 
practice, then, the pill provides an impenetrable barrier to control acquisitions. As long as the pill remains in place, no other defensive measures are necessary because the bid is completely blocked. Defensive measures might be needed, at most, to protect the pill itself.

Protecting the pill, however, is not as easy as it might seem because at any time a pill can be redeemed by the target's board. This provision allows the target board to permit a friendly bidder to proceed, but it also allows a hostile bidder to redeem the pill and proceed with its own bid if it can gain control of the target's board. Efforts to cut off this line of attack by making pills nonredeemable ("no hand" provisions), allowing only continuing directors to redeem the pill ("dead hand" provisions), or delaying redemption for a specified time after a change in board composition ("slow hand" provisions) were invalidated by a New York court in the 1980s and by the Delaware courts in the late 1990s,60 although these pills have been legalized in Pennsylvania, Maryland, and Georgia.61 Thus, at the turn of the millennium, the pill remains vulnerable to a successful proxy attack at the vast majority of public companies.

Moran v. Household International, decided in 1985,62 was the seminal case upholding the poison pill. The Delaware Supreme Court ruled that the business judgment rule applied to Household's decision to adopt a poison pill but was careful to state that the right to use a pill was not "absolute": "When the Household Board of Directors is faced with a tender offer and a request to redeem the Rights, they will not be able to arbitrarily reject the offer." 63 The court went on to explain that managerial decisions to redeem the pill when faced with a tender offer would be subject to judicial scrutiny under Unocal. 64

bid for that company. The threat was sufficiently credible that Crown Zellerbach negotiated a friendly deal with Goldsmith. See Mike Tharp, Goldsmith Wins Fight for Crown Zellerbach Corp., WALL ST. J., July 26, 1985, at 3. This bid was cited in Moran as evidence that the pill was not impermeable. However, both the Crown Zellerbach pill and the Moran pill only had "flip over" triggers, not the more potent "flip in" triggers that soon became commonplace.

60. See cases cited supra notes 34-35.

61. See MD. CODE ANN., CORPS. \& ASS'NS § 2-201(c)(2)(ii) (2000) (allowing directors to limit the power of future directors to vote for redemption, modification, or termination of shareholder rights plans for up to 180 days); Invacare Corp. v. Healthdyne Tech., 968 F. Supp. 1578, (N.D. Ga. 1997) (upholding dead-hand pill under Georgia law); AMP v. Allied Signal, No. 98-4405, 1998 U.S. Dist. LEXIS 15617, at*34-35 (E.D. Pa. Oct. 8, 1998) (upholding slow hand pill under Pennsylvania law).

62. 500 A.2d 1346 (Del. 1985).

63. Id. at 1354 .

64. Id. (referring to Unocal Corp. v. Mesa Petroleum Co., 493 A.2d 946 (Del. 1985)). 
Three years later, in City Capital Associates v. Interco Inc.,65 Chancellor William Allen held that a pill being used by the incumbent board to resist a noncoercive tender offer had to be redeemed. The use of the pill to defeat the offer, Chancellor Allen concluded, was not proportionate to any legitimate threat posed by the tender offer. A year later, in Paramount Communications $v$. Time, 66 the Delaware Supreme Court explicitly rejected Chancellor Allen's approach in Interco and seemed to suggest instead that the right to reject a hostile bid was close to absolute, at least in some circumstances: "Directors are not obliged to abandon a deliberately conceived corporate plan for a short-term shareholder profit unless there is clearly no basis to sustain the corporate strategy." 67

The Court found that Time's characterization of Paramount's all-cash, $100 \%$ tender offer as "inadequate" was sufficient basis for Time to pursue its acquisition of Warner and thus (given Paramount's unwillingness or inability to bid for a combined Time-Warner) to deny Time shareholders the opportunity to decide for themselves whether Paramount's bid was inadequate. While Delaware jurisprudence does not say that courts will never order the redemption of a poison pill, there has not been since Time a single case in which redemption of a pill was ordered by a Delaware court. Thus, as a practical matter, a bidder has had to assume in planning a bid that a target could "Just Say No" and retain a pill unless and until the bidder obtained majority control of the target's board.

Moore v. Wallace Computer68 illustrates how far the "Just Say No" defense can go under current Delaware law. Here, the federal district court for Delaware, applying Unocal in the wake of Unitrin,69 held that the Wallace Computer board would receive the protection of the business judgment rule in its "Just Say No" defense against Moore's hostile bid. Applying the twopronged enhanced scrutiny test set out in Unocal, the court first found that the Moore offer posed a threat to Wallace because Wallace shareholders "might tender their shares in ignorance or mistaken belief as to

65. 551 A.2d 787 (Del. Ch. 1988); cf. AC Acquisitions Corp. v. Anderson, Clayton \& Co., 519 A.2d 103 (Del. Ch. 1986) (striking down takeover defenses under Unocal); Grand Metropolitan Public Ltd. Co. v. Pillsbury, 558 A.2d 1049 (Del. Ch. 1988) (same).

66. 571 A.2d. 1140 (Del. 1989).

67. 571 A.2d at 1154 (emphasis added). As some commentators have observed, however, the Court in Paramount $v$. Time expressly noted that Paramount (the bidder) had not raised, and the court was thus not addressing, the question of whether Time (the target) could be required to redeem its poison pill in the face of Paramount's offer.

68. 907 F. Supp. 1545 (D. Del. 1995).

69. Unitrin v. Am. Gen. Corp., 651 A.2d 1361 (Del. 1995). 
management's representations of intrinsic value and future expectations." 70 Applying the second prong of the enhanced scrutiny test, the court went on to approve Wallace's refusal to redeem its poison pill, on the grounds that such defensive tactics were reasonable because they were proportionate to the threat from Moore and "not draconian." 71

The district court's decision in Wallace Computer represents a logical extension of Time-one would be hard-pressed to find a meaningful distinction in the abstract between a corporate strategy that involves a strategic merger (Time) and a corporate strategy that involves internal growth (Wallace). Yet the court's willingness to accept the "shareholder ignorance" argument seems to represent an important extension of "Just Say No." 72 While there may be alternative policy grounds to uphold the "Just Say No" defense, the Wallace court passed on the opportunity to set fiduciary duty constraints on how a target board deploys a pill. If these limits exist, Wallace suggests that they have moved well beyond their cautious origins in Moran.73

\section{The ballot box safety valve.}

In developing the jurisprudence that today allows a target board to maintain the pill indefinitely, the Delaware courts relied explicitly on there being a safety valve against managerial abuse through the shareholder franchise. Because shareholders can replace the board, if the board were to sacrifice shareholder interests by maintaining the pill, the bidder or someone else (e.g., an arbitrageur) could run a proxy contest promising to elect a board that would redeem the pill and clear the way for the acquisition desired by shareholders. Indeed, the Delaware courts, at the same time that they seemed to be giving license to boards to maintain the pill indefinitely and otherwise block a bid, also indicated that they would protect against managerial moves to impede voting by shareholders to remove them.74

70. Wallace Computer, 907 F. Supp. at 1557. It is possible that Delaware state courts might decline to follow the federal court's holding in Wallace Computer, but they have yet to do so or to repudiate the "Just Say No" case in dicta.

71. Id. at 1563.

72. See Neil C. Rifkind, Should Uninformed Shareholders Be a Threat Justifying Defensive Action by Target Directors in Delaware?: "Just Say No" After Moore v. Wallace, 78 B. U. L. REV. 105 (1998).

73. Cf. Jeffrey N. Gordon, "Just Say Never?" Poison Pills, Deadhand Pills, and Shareholder-Adopted Bylaws: An Essay for Warren Buffet, 19 CARDOZO L. REV. 511 (1997).

74. See Unitrin, 651 A.2d at 1373. 
The seminal case on this point is Blasius Industries, Inc. v. Atlas Corp.75 In Blasius, the hostile bidder, Atlas, solicited written consents to increase the size of the Blasius board from seven to fifteen members, as well as to elect eight new members nominated by Atlas. In response, the Blasius board met through conference call and voted to increase the size of the board by two (thus making seven directors no longer sufficient for control). While refusing to adopt a per se rule against such conduct, Chancellor Allen invalidated the Blasius board-packing action on the ground that it violated the shareholders' fundamental right to elect directors: "The shareholder franchise is the ideological underpinning upon which the legitimacy of directorial power rests." 76 Blasius illustrates how the Delaware courts will protect the proxy contest route, because this route provides the basis for the courts' deference to target managers in their use of structural defenses.

In the current legal regime, then, if the board wants to maintain the pill and not sell to a hostile bidder, the only way to gain control passes through the ballot box. The bidder will have to replace the board with one willing to redeem the pill. Such a ballot box victory is required for a bidder whose offer is attractive to shareholders to overcome incumbents' opposition.

\section{The need for a ballot box safety valve.}

Before analyzing the viability of the ballot box safety valve, we pause to determine whether this safety valve is even necessary. It might be argued that having the formal power to "Just Say No" does not mean that the board will use this power to prevent acquisitions that shareholders would like to have. Instead, if market forces and compensation schemes sufficiently align the interests of managers and shareholders, managers might have sufficient incentives to avoid such results. In particular, it might be argued that the carrot stemming from executive compensation schemes provides such incentives to managers.77 Most stock option packages vest immediately in the event of takeover, which may provide substantial gains to executives in the event of a premium acquisition; golden parachutes, too, can provide

75. 564 A.2d 651 (Del. Ch. 1988); see also Stroud v. Grace, 606 A.2d 75, 92 n.3 (Del. 1992).

76. See Blasius, 564 A.2d at 659.

77. See generally Brian J. Hall \& Jeffrey B. Liebman, Are CEOs Really Paid Like Bureaucrats?, 113 Q.J. ECON. 653 (1998) (documenting the dramatic increase in U.S. stock option compensation in the 1990s); Marcel Kahan and Edward Rock, How I Learned to Stop Worrying and Love the Pill, forthcoming U. CHI. L. REV. (2002) (arguing that the increased use of stock options have reduced incumbents' tendency to favor remaining independent). 
extremely large side-payments to managers in the event of takeover.78 If stock options and parachutes are sufficiently large, managers would use defenses to gain bargaining power but in the end would prefer to sell rather than remain independent.

Another reason that a safety valve might not be necessary is the presence of independent directors. Even if the executives on the board wish to remain independent, goes the argument, other directors will not let them do so if accepting the bid would maximize shareholder value. The independent directors will be willing to go along with saying no in order to get a higher price or to seek out a competitive alternative, but they will not agree to cause substantial harm to shareholders because that would hurt their reputation or would subject them to social or professional adverse consequences.79

We agree that the carrot of stock options and golden parachutes and the potential stick supplied by independent directors may sometimes sufficiently align directors and managers with shareholders. When this happens, we do not need a safety valve, because even absolute power to block bids would not be abused. But our premise, as is the premise of Delaware law, is that it would be unwise to rely solely on these incentives to align the interests of managers and shareholders. ${ }^{80}$ Indeed, any inquiry that seeks to evaluate alternative takeover arrangements (short of an outright ban on takeovers) implicitly assumes that these arrangements matter, which is the case only if managers' interests are not always aligned with those of shareholders. While such coincidence might happen occasionally, or perhaps often, it is unlikely to happen always. The takeover context in particular is one in which there is potential divergence between managers' and shareholders' interests. Furthermore, how often managers will do the right thing will depend on the consequences they face when they do not do the right thing. A safety valve that operates well is important not only in cases in which it is actually used, but also in cases in which its presence influences managers to do the right thing on their own.

We therefore proceed under the premise that a safety valve is necessary.

78. See generally John C. Coates IV \& Reinier Kraakman, Valuing Stock-Based Compensation: Executive Pay and Merger Activity in the 1990s (working paper, on file with the authors) (discussing the effect of options and parachutes on incentive to sell).

79. Cf. Interview with partner at major Wilmington, Delaware law firm (Feb. 15, 2001) ("What we [the bidder] want to do is put directors in an irreconcilable position, where they are not willing to sit around and take risks that implicate their fiduciary duty.").

80. See Lucian Arye Bebchuk, The Case against Veto Power in Corporate Takeovers, forthcoming U. CHI. L. REV. (2002) (arguing that managers' and shareholders' interests are likely to diverge significantly in the takeover context and that executive compensation schemes cannot be relied on to eliminate such agency problems). 
In the remainder of this Part, however, we argue that the safety valve is illusory when the target has an ESB. In the next Part we present empirical evidence in support of this view. This theory and evidence is particularly troubling because courts have relied on the ballot box safety valve as if it were viable. In Part $\mathrm{V}$ we discuss how the Delaware takeover jurisprudence should develop to bridge this gap between the theoretical role for the ballot box and its actual functioning.

\section{Three Types of Targets}

We now begin addressing the question of whether and to what extent the ballot box is a viable safety valve. The answer to this question, as we will show below, depends on the speed with which the bidder can gain access to the election mechanism. Targets can be classified into three categories with respect to their vulnerability to a proxy contest: no minimum term (NMT); effective annual term (EAT); and effective staggered board (ESB). In this Part we describe each of these three categories in more detail. In the next Part we examine the delay imposed on the proxy route for a hostile bidder facing targets in each of these categories.

\section{No minimum term.}

Consider the scenario in which the target has a pill, but does not have any other structural defenses that would prevent the bidder from marshaling support from shareholders to replace the board immediately. We classify these targets as no minimum term (NMT) targets. To fit into this category, the target's shareholders must have the ability to act by written consent81 or act through special meeting.82 In addition, the target's shareholders must have the ability either (1) to remove directors without cause (and then petition the court to order a new election of directors);83 or (2) to "pack the

81. Delaware firms may act through written consent unless prohibited in the firm's charter or bylaws. See DEL. CODE ANN. tit. 8, § 228(a) (2000). Forty-two states that follow the RMBCA reverse this rule, allowing shareholders to act only through unanimous written consent (which effectively bars action through written consent). See MODEL BUS. CORP. ACT $§ 7.04$ (1999).

82. Delaware firms are prohibited from calling a special meeting unless otherwise specified in their charter or bylaws. See DEL. CODE ANN. tit. 8, § 211(d) (2000). Fortyone states that follow the RMBCA reverse this rule, allowing shareholders to call a special meeting on the call of $10 \%$ of the shareholders, unless prohibited at the firm level. See MODEL BuS. CORP. ACT § 7.02 (1999).

83. See Del. CODE ANN. tit. 8, § 141(k) (2000) (allowing removal of directors without cause unless there is a staggered board); MODEL BUS. CORP. ACT $\S 8.08$ (1999) (allowing 
board" by increasing the number of directors and filling the vacancies created. 84

Against an NMT target, the bidder will announce its offer and run a proxy contest to replace the board, either through special meeting or through shareholder written consent. If elected, the slate offered by the bidder will commit to withdrawing the pill and accepting the bidder's offer. The proxy contest, therefore, will essentially be a referendum on the offer. Shareholders will vote in favor of the bidder's team if and only if they view the bidder's offer as superior to remaining independent.

An NMT target produces a regime that can be referred to as one of "shareholder voting and no board veto." 85 The need to win a proxy contest eliminates the pressure to tender and thus ensures that no bidder whose offer does not enjoy genuine shareholder support can gain control. Without the requirement of winning a vote, shareholders may tender to the hostile bidder, even if they do not judge the offer to be value maximizing, for fear of ending up with minority shares in the taken over target.86 The proxy contest eliminates this collective action problem, because shareholders will not be penalized if they vote against the bid and the bid is still approved. Therefore, shareholders will not vote in favor of the bid unless they want the bid to succeed. The bidder will win the referendum only if a majority of the shareholders view the offered acquisition price as exceeding the target's independent value, an "undistorted choice" that yields the socially optimal outcome.87

In short, a proxy contest provides a viable safety valve in the specific context of an unstaggered board that can be removed immediately. IBM's

removal without cause regardless of whether there is a staggered board); see also Bebchuk, Coates \& Subramanian, supra note 3; Coates, supra note 2, at Appendix B.

84. DEL. CODE ANN. tit. 8, § 141(b), § 142(e) (2000) (allowing number of directors to be set in either the by-laws or the charter and providing that the board shall fill vacancies unless otherwise provided for in the by-laws); MODEL BUS. CORP. ACT $\S$ 8.03(a), § 8.10(a) (1999) (allowing the number of directors to be set in either the by-laws or the charter and allowing either shareholders or the board to fill vacancies).

85. See Bebchuk, supra note 80 (describing and defending the general case for such a regime).

86. See Lucian Arye Bebchuk, The Pressure to Tender: An Analysis and a Proposed Remedy, 12 DeL. J. CORP. L. 911 (1987); Lucian Arye Bebchuk, Toward Undistorted Choice and Equal Treatment in Corporate Takeovers, 98 HARV. L. REV. 1693 (1985). For a formal model of the pressure-to-tender problem and how voting can address it, see Lucian Arye Bebchuk \& Oliver Hart, Takeover Bids vs. Proxy Fights in Contests for Corporate Control (John M. Olin Center, Harvard Law School, Working Paper No. 336, October 2001), available at http:/ / papers.ssrn.com/abstract=290584.

87. See sources cited supra note 86 . 
hostile bid for Lotus illustrates how this mechanism can work. In June 1995, after months of friendly overtures, IBM launched a \$60-per-share all-cash hostile bid for Lotus, representing more than a $100 \%$ premium over Lotus's pre-bid share price (though only a slight premium to its 52-week high of \$59.50). IBM also solicited written consents from shareholders, as permitted by Delaware law,88 seeking to replace all six Lotus directors. Lotus, meanwhile, declared the offer inadequate and searched for a white knight, reportedly approaching AT\&T, Hewlett-Packard, and Intel.s9

On June 12, less than a week after IBM announced its offer, Lotus capitulated and agreed to a sweetened \$64-per-share friendly deal. The breathtaking pace of the deal, "one of the fastest capitulations ever in a hostile takeover," 90 occurred because IBM was able to force a shareholder referendum that it almost certainly would have won. Thus, without any provisions that delay or complicate the election process, the pill does not enable managers to impede for very long an offer that shareholders find attractive. As IBM/Lotus illustrates, the proxy contest safety valve works effectively when the board is not staggered and immediate removal is possible.

\section{Effective annual term.}

Now consider a scenario in which the bidder cannot replace the target board immediately, but can do so at the next annual meeting of shareholders. We classify these targets as effective annual term (EAT) targets. To fit into this category, the target must have eliminated the ability for shareholders to act by written consent and the ability to act at a special meeting or, alternatively, have both eliminated the power of shareholders to remove directors without cause and eliminated the ability of shareholders to "pack the board." In addition, if the board is staggered, the hostile bidder must be able to dismantle the staggered board at the annual meeting in one of the ways specified above.91

As with NMT targets, in this scenario the bidder will announce its offer and run a proxy contest to replace the board. If elected, the slate offered by the bidder will commit to withdrawing the pill and accepting the bidder's

88. See Del. CODE ANN. tit. 8, § 228(a) (2000) (permitting shareholder action through written consent).

89. See Steven Lipin \& Laurie Hays, IBM Is Seeking to Force Ouster of Lotus Board, WALL ST. J., June 7, 1995, at A3.

90. See Laurie Hays \& Steven Lipin, Lotus Gives In and Accepts IBM Offer of $\$ 3.52$ Billion, a Sweetened $\$ 64$ a Share, WALL ST. J., June 12, 1995, at A3.

91. See supra text accompanying notes 83-84. 
offer. The only difference between EAT and NMT targets is that here the bidder will have to wait until the next annual meeting of shareholders, which could be as long as thirteen months away, 92 before it can get an up-ordown verdict from shareholders.

In many cases, the bidder might be unable to wait - the bidder may need to plan, may need to know where it stands, etc. Furthermore, the benefits might dissipate if the bidder has to wait-for example, if the bidder needs certain assets now, not a year from now. Therefore, because a significant delay might be required before a proxy contest can be launched, the ballot box route may not provide a sufficient safety valve against disloyal incumbents of EAT targets in some cases. Thus, incumbents of EAT targets sometimes have significant power to block offers that shareholders would support.

As assessment of the antitakeover consequences of EAT arrangements is beyond the scope of our project. The above discussion, however, indicates that EATs do not generally foreclose the ballot box route, for two reasons. First, bidders can always win control of the board by winning a one-time proxy contest. Second, although some bidders would have to wait as long as thirteen months before being able to run such a contest, bidders that emerge not far from the next annual meeting would not have to wait that long. However, there is a third class of targets - those with "effective staggered boards" - for which the ballot box route is hardly viable.

\section{Effective staggered board.}

The third scenario-and the one on which we focus for the remainder of this Paper - is the scenario in which the bidder must go through two annual meetings in order to gain majority control of the target's board. We classify these targets as effective staggered board (ESB) targets. To fit into this category, the target must have a staggered board, with at least three classes of directors, 93 which cannot be dismantled in any of the three ways specified above.94

92. See Koppes, Ganske \& Haag, supra note 10.

93. A hostile bidder could gain $50 \%$ control of the board in just one proxy contest against a target with two classes of directors. (A particularly lucky hostile bidder might even win control of the board in one election if the target had an odd number of directors and the proxy contest were brought in the "right" year.) This qualification is technically necessary, though few staggered boards have only two classes of directors. For ease of exposition we assume a three-class staggered board throughout the remainder of our analysis (which is by far the modal staggered board). Our arguments on the potency of ESBs take on even more force if the staggered board has four classes.

94. See supra text accompanying notes $83-84$. Note that shareholders' ability to call a 
In this scenario, the bidder has no choice but to wait through two annual meetings in order to gain control of the board. 95 As with NMT and EAT targets, the bidder will announce its offer and run a first proxy contest to gain one-third of the target's board seats. Unlike NMT and EAT targets, however, the bidder's candidates will not be able to commit to withdrawing the pill if elected, because they will be in the minority. Instead, they will bide their time for a year, until a second annual election of directors will (hopefully) give the bidder a majority of board seats. At that time the board will vote to redeem the pill, paving the way for the target to accept the bidder's offer.

U.S. Surgical's hostile bid for Circon illustrates the difficulty of this route. 96 In August 1996, Surgical launched a 100\% cash tender offer for Circon at $\$ 18.00$ per share, representing almost a $70 \%$ premium over the preannouncement share price. On the advice of Circon's outside counsel Wilson Sonsini, Circon installed a "morning after" poison pill with a $15 \%$ trigger immediately after the Surgical bid was launched. Circon's staggered board was provided in the charter, but Circon's bylaws specified that the number of directors would be set by a majority vote of the board.97 While this configuration of defenses suggested at least the potential for board packing, Circon's bylaws also specified a two-thirds vote requirement (of outstanding shares) 98 that effectively eliminated this route.99 Taken together, these

special meeting and shareholder ability to act by written consent are irrelevant in determining whether the target has an ESB. The reason is that even if shareholders can act early, if they cannot dismantle the staggered board then there is no action that they can take.

95. If the target has cumulative voting, and if insiders own a sufficiently large stake, then it may take three elections for the bidder to gain control of the board because the insiders may be able to preserve one seat in each election. For example, if there are three classes of three directors each, and insiders own $34 \%$ of the shares, insiders can elect one director in each election. See CLARK, supra note 55, at 363 (defining minimum number of shares required to elect one director under a cumulative voting system). After two elections, the bidder would have won four seats (not six) and still would not control a majority of the board. For our analysis we make the simplifying assumption that the target does not have a cumulative voting system. In fact, cumulative voting is relatively uncommon-in our IRRC sample, for example, approximately $10 \%$ of firms with staggered boards also had cumulative voting, yielding $6 \%$ of the total sample that had both a staggered board and cumulative voting. As above, see supra note 93, our arguments on the potency of ESBs take on even more force if the target has cumulative voting and insiders have a significant stake.

96. See Hall, Rose \& Subramanian, supra note 33.

97. Circon Bylaws § 3.3.

98. Circon Bylaws § 9.2.

99. Circon CEO Richard Auhll owned $12 \%$ of the company, and company insiders 
provisions blocked removal and board packing and gave Circon an ESB. Surgical therefore began the prolonged process of going through two annual meetings to gain control of Circon.

In October 1997, more than a year after the bid had been launched, Surgical put up a dissident slate of directors and won two seats on Circon's board. Plans to put up a second slate of directors in October 1998, which would have almost certainly led to gaining control of the Circon board, were cut short when Surgical sold itself to Tyco in June of that year. Because Tyco had a policy of not making hostile acquisitions, Surgical withdrew its bid for Circon. In September 1998, under pressure from arbitrageurs (who threatened to run their own slate of directors), Circon sold itself in a friendly deal to Maxxim Medical Inc. for 17\% less than the original Surgical bid, two years earlier.

Surgical's bid for Circon illustrates the difficulty of the proxy route. In fact, to our knowledge, no bidder has successfully fought through two proxy contests to win control of an ESB target.100 This fact suggests that the ballot box is not a viable safety valve against an ESB target. The next Part provides a theoretical explanation for why this is true.

\section{The Delay Problem}

This Part examines how quickly a hostile bidder can gain control of a target through the proxy contest route. To assess the delay problem, we compare the three types of targets that we defined earlier -NMT targets, EAT targets, and ESB targets. In addition, we analyze the delay that would be imposed against hostile bidders in two hypothetical regimes-targets

(employees and directors) held another 13\%. See Hall, Rose \& Subramanian, supra note 33 , at 4 . Thus Surgical would have had to win $89 \%$ of the remaining shares in order to successfully amend the bylaws. While this would have been at least mathematically possible, it was made even more difficult by the fact that $10-15 \%$ of the shares typically do not vote, for miscellaneous reasons, in proxy contests (e.g., they are out of the country, or they do not know they own the stock). Surgical could afford, at most, $8 \%$ shareholder nonparticipation, and $100 \%$ voting in favor among the remaining shareholders, in order to successfully pack the board. That Surgical did not even attempt this route - and chose instead the "easier" path of waiting through two annual elections-suggests its difficulty.

100. See infra Part IV.B.2. When this Article was presented at a "bridge group" of academics and practitioners at New York University Law School in April 2001, some practitioners claimed to recall situations in which a bidder had in fact won two elections against an ESB, but no one could provide a specific example of such an event. If such examples exist, they occurred before 1996-in Part IV we examine all proxy contests against ESBs between 1996 and 2000 and find no contests in which a bidder had won two elections against an ESB. 
with effective biennial terms, in which a single class of directors is elected every other year (and midterm removal is not possible), and targets with effective triennial terms, in which a single class of directors is elected every third year. We first consider the average delay that is imposed against hostile bidders, and then we turn to the minimum delay that is imposed.

\section{Average delay.}

We make some simplifying assumptions without loss of generality. First, we assume that once a hostile bidder emerges, it has infinite patience and determination and will continue to pursue the deal to completion.101 Second, we assume that the target's shareholders are unanimously in favor of the bid and will vote for the bidder in any elections that take place. Third, we assume the target's incumbent board (which by assumption does not own any shares) is unanimously against the bid and will take all possible actions (to the extent permitted by the law) to prevent the bid from succeeding.

Comparison of existing regimes. With these assumptions in place, we now calculate how long it will take for the bidder to acquire control after initiating a hostile bid that shareholders would like to accept. The simplest case is NMT targets. Here, the hostile bidder can gain control within a matter of months, regardless of when the bid is launched relative to the annual shareholders meeting. IBM's hostile bid for Lotus, described in Part III.C.1. above, provides the clearest example of this case. For simplicity, we describe the delay imposed against NMT targets as zero.102

Next we consider EAT targets. Within this category, when the incumbent board loses a single proxy contest, it is out of office and the hostile bidder wins. Accordingly, the longest delay that would be imposed against an EAT target would be a full year, if the bidder appeared immediately after the target's shareholder meeting. The shortest delay against an EAT target would be zero, if the bidder appeared immediately before the target's shareholder meeting. If we assume that hostile bids are distributed uniformly throughout the year and are uncorrelated with annual meeting

101. Later we explore the implications of relaxing this assumption. See infra Part III.D.2.

102. For completeness, we note that even bids for NMT targets are subject to some legal delay, due to SEC filing requirements and notice requirements under state law and target charters and bylaws. Targets vulnerable to written consent solicitations will be more vulnerable than those vulnerable to special meeting calls, because a consent solicitation takes effect when filed with a target, whereas a special meeting typically requires a solicitation to call the meeting and another solicitation to obtain proxies for use at the meeting. Still, the general point is that NMT targets are vulnerable to much more rapid proxy fights (and hence, bids) than EAT and ESB targets. 
dates, 103 then the average delay imposed against EAT targets is six months.

Now consider the case of ESB targets. With an ESB, unlike an EAT, losing the first battle does not mean losing the war for the target's board. Against an ESB, a hostile bidder will have to win two proxy contests in order to gain majority control of the board. If the hostile bidder appears immediately after the target's annual meeting, it will wait one year, win a first election, wait another year, and finally have majority control of the board after two years. If the hostile bidder appears just before the target's annual meeting, it will win one-third immediately, but will have to wait another year to gain control, resulting in a total wait of one year. On average, and assuming the same uniform distribution of bids as described above, a hostile bidder against an ESB will face a delay of one-and-a-half years.

Recall the argument that Clark, Gilson and others made,104 and with which we agreed,105 that, before the pill, directors would not hide behind their staggered board but would resign if a bidder bought a majority of the shares. Couldn't one similarly expect that, even after the pill, if the board loses one election, it would in fact resign even though it could stay in power for another year? The answer is no. The reason is that the incumbents still have a reason to fight with an ESB. Before the pill, when a bidder acquired a majority of the shares, further resistance would be futile. It would simply be a matter of time before the target would be required to hold the perfunctory annual meeting that would displace an additional one-third of the board, thus giving the bidder control. Furthermore, it would seem illegitimate or at least hardly respectful to cling to power for another year when the majority shareholder wishes you to leave. Far better to exit gracefully, in this scenario, than be forced out one year later.

In contrast, with an ESB, when a bidder wins the first election, the fight against the bidder is not doomed, because it is far from certain that the

103. This assumption is valid if bidders make bids immediately after identifying targets that they would like to purchase and if such findings and the business needs of bidders are in no way correlated with the election calendars of targets. Admittedly, this assumption is not completely valid - in a preliminary analysis we find that more than half of all annual meetings occur in April and May and that there is a slight increase in hostile bid activity in the preceding two to three months. This sensitivity to annual meeting date is slightly greater against targets with ESBs. These findings suggest that the observable delay against the various types of targets, and particularly against ESBs, is slightly less than we estimate in our theoretical analysis. Still, as we show in Part IV, the impact of ESBs on bid outcomes is substantial.

104. See Clark, supra note 55; Gilson, supra note 55.

105. See supra text accompanying note 56. 
bidder will win the next election or even stay in the game until then.106 In the context of U.S. Surgical's hostile bid for Circon, for example, Circon board member George Cloutier provided this advice to his CEO, friend, and Harvard Business School sectionmate Richard Auhll:

I told Richard "Let's just wait it out." You never know what is going to happen. We're not going to give up here. We're staying until the last gun is fired. ... That was my position: we fight until the last minute, last day, last hour, and something will happen. And I was actually right.107

Indeed, with an ESB in place, a target board can reasonably attempt to wait it out. The target's share price may increase through the bid price (as was the case with Wallace Computer), a white knight may appear (Younkers), the bidder may lose interest or its ability to pursue the bid (Circon), or other unforeseeable circumstances may intervene (For example, accounting fraud at Cendant forced it to abandon its bid for American Bankers.108). Furthermore, with the shares held by others than the bidder, the board would be able to assert that it is serving the legitimate goal of protecting its shareholders. Thus, with the pill, the board will no longer exit gracefully after losing the first proxy contest. Dissident directors may be uncomfortable or a nuisance to the incumbent board members, but with an ESB dissidents have little to no real power after a single election.109

Comparison to alternative regimes. For comparison purposes, we now examine the average delay under two hypothetical regimes. First, consider biennial elections of a single class of directors, without any possibility for

106. See John C. Coates IV, An Index of the Contestability of Corporate Control: Studying Variation in Legal Takeover Vulnerability (working paper July 17, 1999).

107. Interview with George Cloutier in Waltham, Mass. (Sept. 8, 2000), transcript at 15 (on file with the authors).

108. This example is imperfect because the fraud occurred after Cendant's bid had been accepted. See Emily Nelson, Leslie Scism \& Steven Lipin, Cendant Stock Plummets $46.5 \%$ on News that Accounting Woes Hurt Earnings; Pending Plan to Acquire American Bankers Is Put in Doubt by Price Drop, WALL ST. J., Apr. 17, 1998, at A3.

109. See, e.g., Memorandum from Richard Auhll to Circon employees (Sept. 30, 1997) (" [K]eep in mind that even if U.S. Surgical wins two seats on our Board, they will not have a majority and cannot force a sale of the Company. So although they may make a big deal about the results of the election, the reality is, little actually changes."), quoted in Brian Hall, Christopher J. Rose \& Guhan Subramanian, Circon (B) (Harvard Business School Case Study N9-801-404) (Mar. 19, 2001). For a view from the other side, consider the comments of Charles Elson, dissident director on the Circon board: "We were surrounded. Brute [Krulak, the other dissident director,] and I were on opposite sides of the table, and the rest of them were all around us." Hall, Rose \& Subramanian, supra note 33 , at 10 . 
removal in between elections. As noted earlier, all states, including Delaware, are generally thought to require an election each year.110 Under this hypothetical regime, if the bidder emerged just before an election, it would not have to wait at all, and if it emerged immediately after an election (and thus two years away from the next election), it would have to wait two years. Assuming (as above) a uniform distribution of bids uncorrelated with annual meeting dates, the average delay under a biennial election arrangement would be one year. Thus a target with biennial elections would lead to longer delay, on average, relative to an EAT target (one year versus six months), but shorter delay relative to an ESB target (one year versus eighteen months).

As a second alternative regime, consider a triennial election of a single class of directors. If a bidder emerged immediately before an election, it would not wait at all; if it emerged immediately after an election it would have to wait three years. The average wait would be one-and-a-half years, which is the same delay as against an ESB target. This fact suggests that ESBs provide the same average delay against a hostile bidder as a triennial election of a single class of directors. We now show, however, that other considerations might make ESBs even more powerful against hostile bids than a three-year single-class arrangement.

\section{Minimum delay.}

So far we have limited our comparison to the average delay. Of course, any given bidder is influenced not by the average delay but by the delay in its particular case. We therefore now consider the distribution of potential lengths of delay. Table 1 summarizes the analysis from the previous section:

110. See supra notes 7-8 and accompanying text. See also Robert Frank, Comcast, ATET BroadBand Protect Board, WALL ST. J. (Feb. 13, 2002) at C16 (noting that ComcastAT\&T Broadband charter does not allow an election of directors until 2005, and stating that "merger attorneys say they know of no other cases where an entire board was locked up for two years or more"). This provision of the Comcast charter is currently being challenged under Pennsylvania corporate law. See Jaret Seiberg, Investors Sue in \$42B Comcast Deal, The Daily DeAL (Feb. 20, 2002). 
Table 1: Delay Imposed by Various Target Defenses (in years) Minimu Maximu Average

\begin{tabular}{lccc} 
& m & m & 111 \\
\hline $\begin{array}{l}\text { No Minimum Term } \\
\text { (NMT) }\end{array}$ & 0 & 0 & 0 \\
$\begin{array}{l}\text { Effective Annual Term } \\
\text { (EAT) }\end{array}$ & 0 & 1 & $1 / 2$ \\
$\begin{array}{l}\text { Effective Staggered Board } \\
\text { (ESB) }\end{array}$ & 1 & 2 & $1^{1 / 2}$ \\
$\begin{array}{l}\text { Biennial Election of a } \\
\begin{array}{l}\text { Single Class } \\
\text { Triennial Election of a }\end{array}\end{array}$ & 0 & 2 & 1 \\
$\begin{array}{l}\text { Single Class } \\
\text { a }\end{array}$ & 0 & 3 & $1 \frac{1 / 2}{}$
\end{tabular}

Table 1 shows that, under a three-year arrangement, delay ranges from zero years to three years. Thus the possibility remains open that a bidder lucky enough (or astute enough112) to emerge close to the next election would have to bear only a small delay in the event that the incumbent board rejects its offer. In contrast, with an ESB, delay ranges from one year to two years - under no circumstances can a bidder get a referendum on its offer without a delay of at least a year.

This difference is critical. At the outset of this Part we assumed that bidders have infinite patience and determination. However, there are many potential bidders whose patience is more limited. Buyers often need to have resolution, and cannot allow the question to remain unresolved for more than a year. Consider a buyer that needs a certain type of asset. If it does not ultimately buy target $\mathrm{T}$, then the buyer should acquire another company instead (or build the asset in-house). If T has an ESB and T's board is unwilling to sell, the buyer would be foolhardy to wait for a year (or longer) to determine whether its hostile bid against $\mathrm{T}$ will succeed. Instead the buyer should look elsewhere. Therefore an ESB should provide incumbents virtually complete protection from hostile bids, with all of the potential drawbacks in terms of managerial agency costs that are associated with such insulation. In contrast, a three-year arrangement may or may not provide such protection, depending on when the bidder happens to emerge in relation to the time of the scheduled election.

Putting the same point slightly differently, an ESB condenses the distribution of delays toward the middle when compared to a triennial

111. This calculation assumes that bids are distributed uniformly throughout the year and are uncorrelated with shareholder meeting dates.

112. See supra note 103. 
election of directors. It eliminates those cases in which the delay will be less than a year, but also eliminates those cases in which the delay will be more than two years. The first effect buys incumbents more protection than the possible reduction in protection caused by the latter effect. Having a significant possibility that a hostile bidder will face only a short delay will make the incumbent vulnerable. In contrast, shortening delay from two-anda-half years to one-and-a-half years does not create large incremental exposure for the target board, because one-and-a-half years is still a long time in a dynamic business environment. In short, the elimination of any possibility of delay below one year closes an important window of vulnerability, whereas the reduction of delay to the still long delay of one or two years is unlikely to have a significant impact.

\section{E. The Two-Election Problem}

So far we have seen why an ESB would impose a heavier burden on a hostile bidder than even a triennial election of directors, in terms of the delay in taking over the board. But there is another dimension, beyond mere delay. When all directors can be removed together, a bidder would have to win only one election. In contrast, an ESB requires such a bidder to win two elections, one year apart. This two-election requirement imposes an additional significant hurdle.

To see why, consider two situations, both with the same delay. In one scenario the bidder needs to win only one election, and in the other scenario the bidder needs to win two elections. To be concrete, compare (i) a situation in which all directors are elected to two-year terms, and in which a bidder emerges fifteen months before the next election; with (ii) a situation in which there is an ESB and a bidder emerges three months before an election. In both situations, delay would be fifteen months before the bidder could gain control of the board. But, as explained below, situation (ii) is more difficult for the bidder to gain control because, even though the total wait would be the same, the bidder would have to win two elections one year apart.

The problem is this: In the case of one election, once it comes, however distant in the future, the buyer will know how much it is willing to pay for the company, and will put an offer on the table. In example (i) above, the hostile bidder will wait until the election and then run a proxy contest. The bidder will announce its acquisition price concurrently with the proxy fight, which it will set on the basis of its own and general market conditions.

In situation (ii), with two votes a year apart, the bidder faces a problem. In the first election, if the bidder does not make a firm offer for the target, target shareholders will be reluctant to vote for the bidder's slate, and the bidder's chances of success will be diminished. If the bidder makes a firm 
offer, however, the bidder will expose itself to risk - essentially the bidder will be providing the target shareholders with a year-long put option for their shares. For this reason two elections are far more difficult than one. In the discussion below we start with the general problem of winning the proxy contest without a firm offer on the table, and then turn to additional difficulties presented by an ESB.

\section{The importance of a firm offer for winning a proxy contest.}

There are strong reasons to believe that when a bidder in a proxy contest for control does not make an acquisition offer, it will be difficult for the bidder to win.113 Shareholders will be reluctant to vote for a bidder that does not put an acquisition offer on the table. The bidder might be interested in pursuing its own interests rather than increasing shareholder value. Because winning would provide the bidder with private benefits of control, shareholders cannot infer from the mere mounting of a fight that they will be better off if the bidder wins. Their welfare will depend on how the bidder and the incumbents compare, an assessment that shareholders may not be well-positioned to make. Being imperfectly informed about the quality of the bidders, the shareholders might vote on the basis of the average quality of bidders, which might lead them to vote generally against bidders in proxy contests not backed by a firm acquisition offer. This argument is consistent with empirical evidence suggesting that proxy contests for control, without an accompanying tender offer, are seldom successful.114

By making a firm offer for the target's shares in conjunction with its proxy fight, a bidder eliminates the need for shareholders to make an assessment of how well the bidder would run the firm. Instead, to determine

113. For a fuller analysis of this point, using a formal model of voting with and without an acquisition offer on the table, see Lucian Arye Bebchuk \& Oliver Hart, Takeover Bids vs. Proxy Fights in Contests for Corporate Control, (Working Paper No. 336, John M. Olin Center, Harvard Law School, October 2001).

114. While we argue that it is difficult to win a first election without having a firm offer on the table, we do not claim that it is impossible. There have been situations in which shareholders are so dissatisfied with existing managers that, notwithstanding the considerations discussed here, they have voted for a challenger. In our hostile bid sample, described in more detail in Part IV below, only one bidder was successful in winning the target by bringing a proxy contest without an accompanying tender offerthis was Huntsman's July 1996 offer to acquire Rexene Corp. Note that even in this bid there was a specific offer on the table ( $\$ 15$ cash per share, eventually increased to $\$ 16$ cash), though the bidder did not make a formal tender offer. The proxy route on its own may have been more effective than usual in this case because it was initiated by Guy Wyser-Pratte, a 10\% holder of Rexene and a noted shareholder activist. 
whether they would be better off, shareholders simply need to compare the offer price (which is much less speculative than the expected monetary value of the company under the bidder's management) with their assessment of the target's value.

\section{The importance of a firm offer against an ESB.}

We now turn to the specific case of a first proxy contest against an ESB to elect one-third of the board. Here, the contest is not over full board control but rather over a rival team putting its foot in the door. For the reasons described above, the bidder would find it difficult to win the proxy contest unless it put a firm offer on the table. In the specific context of an ESB, there are two additional reasons that a firm offer is necessary. First, shareholders may not want to let the bidder infiltrate their board with a minority of directors, who could then conduct due diligence from the inside and report back to the bidder, unless there was a firm commitment on the offer. Second, it may be costly to have a hostile, dissenting group on the board.115 Thus, if the bidder is not going to make an offer in a year (as happened in the end in Circon), putting the bidder's team on the board for now is costly. Circon Chairman and CEO Richard Auhll described the enormous difficulty in running his company with a hostile takeover bid pending and two dissident directors on his board:

We were terrified that we would lose our employees and that would destroy our ability to operate the company. That was a major, major issue, trying to hold our team together. ... So I was a major cheerleader out there for the employees, trying to keep up morale and keep the esprit de corps up.... We spent a lot of money on incentives for the sales force to stay in place, because the sales force was vital to the whole issue. And it turns out, those efforts were not successful. No matter how much money we threw at it, it was not enough to keep the sales force in place.... Over the full 26 month period [of the hostile bid], our sales remained basically level.116

Electing a minority dissident slate can be thought of as an investment by shareholders in the bidder's program. If the bidder does not complete its takeover a year later, then shareholders do not get their "payoff" from this investment, and would have been better off not putting a disruptive group on the board in the first place.

115. See, e.g., Topps Co. Proxy Statement, Proposal No. 4 (May 28, 1998) (“A proxy fight, regardless of whether successful, can seriously distract a company's management and board of directors and impose substantial costs on the company.").

116. See Hall, Rose \& Subramanian, supra note 33. 


\section{The cost of committing to a price.}

What is so difficult in having to make a bid (or some strong commitment to a price) in the first election? Why would this deter or make difficult some potential acquisitions? The problem is that in a dynamic world the value of the target can change over time; thus making an irreversible or even strong commitment to a price for a considerable period exposes a bidder to substantial risk.

To illustrate, consider a bidder that emerges when the independent value of the ESB target is $\$ 100$. Assume the best case - the next annual meeting is imminent, and the following annual election is a year after that. Assume further that the target will have either positive developments or negative developments over the next year, and as a result the value of the target as an independent entity will be either $\$ 130$ or $\$ 70$, each with a $50 \%$ probability. Finally, assume that the bidder can manage the assets more efficiently, or can produce gains from synergy, which makes the value of the assets to the bidder $120 \%$ of the independent value of the target. This final assumption means that if the bidder were able to wait until a year from now and then make an offer, the bidder would always be able to make an offer that shareholders would find attractive. ${ }^{117}$

Now let us turn to the bidder's predicament if the bidder needs to win two elections, one now and one in one year. We have argued in the previous section that the bidder needs to commit to a price now that it will keep open until the next election. What price $(\mathrm{P})$ should the bidder offer now, just before the first election? If the bidder makes a firm offer of $\mathrm{P}$ and binds itself to it for a year, shareholders will be free to accept or reject it later on, and the target board will be free to bring in rivals with competing offers.

For example, consider what would happen if the bidder were to offer a price of $\$ 110$, open for one year. This offer would be enough to win now, if there could be a decisive referendum now. In a year, if the target has positive developments, the independent value of the target would go up to $\$ 130$, and shareholders would reject the offer. If the target has negative developments, the independent value of the target would decline to $\$ 70$, and shareholders would accept the offer. Of course, in the event of negative developments getting the target for $\$ 110$ will be a losing proposition for the bidder, who would value it only at $\$ 84(\$ 70 \times 120 \%)$.

The problem is that making a firm offer at $\$ 110$ - or at any other priceeffectively gives target shareholders a put option for their shares. In a single-

117. Note that the bidder cannot commit now to bid $120 \%$ (or something between $100 \%$ and $120 \%$ ) of the market price one year later because as the commitment date approached the target's share price would be bid up without any clear limit, stopping only at the point at which the bidder's commitment to the offer were no longer credible. 
election regime, the option is not worth a great deal because it expires relatively quickly. In a two-election regime, giving the option is costly because it will extend for one year or longer. ${ }^{118}$ In the simple numerical example provided above, the bidder will win only when the target experiences negative developments, but of course in this scenario the bidder does not want to win. The only solution to this manifestation of the classic "lemons problem" is for the bidder not to bid. Thus, in this example, even though the value of the target's assets would be higher in the hands of the bidder, there is no firm offer that would enable the bidder to win the first round yet would be profitable for the bidder to make.119 The bidder will be unwilling to make a firm offer or will reduce the amount that it would be willing to offer, either of which would make it more difficult to win the requisite two elections.

We do not claim that it is impossible for a bidder to win two elections. If the shareholders are sufficiently desperate about their existing situation they might be willing to vote for the bidder even without a firm offer. And if the bidder values the target sufficiently highly, it might be worthwhile to bear the cost of making a firm offer. Our point is only that the two-election problem imposes an additional and substantial cost that makes the ballot box route extremely difficult.

\section{Comparison to the one-election case.}

To close this Part, it is worth highlighting the difficulty of having to win twice by noting how the volatility of the assets of the target over time would not be an impediment in a case in which the bidder faced delay but did not need to win two separate elections. Using the bidder in the above numerical example, assume an election arrangement in which the bidder would have to wait a year and then could run one proxy contest for the board as a whole.

In this case, assuming that the bidder is willing to bear the cost of delay, the volatility of the assets over the interim year would not be a problem, because the bidder could simply observe the target's asset value just before

118. In theory the bidder could adopt a hedging strategy that would provide insurance against the value of the target going down, but this strategy would simply replace the implicit cost of the free put with an explicit cost of the premium needed to purchase such insurance. Basic option theory predicts that these two costs should be equal.

119. For simplicity we have presented an example with two discrete outcomes ( $\$ 70$ or \$130), but the argument continues to hold if we allow a continuous distribution of outcomes. As long as the value of the target could fall below $\$ 92$ as a stand-alone entity (which means that the value to the bidder would fall below $\$ 110$ ), the put option at $\$ 110$ is costly for the bidder to give. 
making its bid. If the target had positive developments and its value increased to $\$ 130$, the bidder would bid somewhere between $\$ 130$ and $\$ 156$ (120\% of $\$ 130)$. If the target had negative developments and its independent value went down to $\$ 70$, the bidder would bid somewhere between $\$ 70$ and $\$ 84$ (120\% of \$70). This example illustrates the point that the existence of one definitive election enables the bidder to makes its final commitment to price just before the outcome is resolved through the proxy contest. Unlike the ESB scenario, in this scenario bids are not deterred.

The analysis in this Part demonstrates that even in those cases in which an ESB and a two-year (or three-year) arrangement would present the bidder with the same delay, the former would constitute a much more formidable takeover defense. Under the latter, if the bidder is sufficiently patient (a big "if" to be sure), the bidder will be able to eventually reach an up-or-down referendum on an offer it will be able to determine at the time of the referendum. With an ESB, however, this possibility does not exist.

\section{F. Conclusion}

In closing this Part, we return to our initial objective, which is to assess the viability of the ballot box safety valve against disloyal target boards. In Part III.C we argued that it is necessary to distinguish among three types of targets in order to answer this question: (1) targets with no minimum term for board members ("NMT targets"); (2) targets which have an effective annual term ("EAT targets"); and (3) targets with effective staggered boards ("ESB targets"). The ballot box is a meaningful safety valve against NMT targets, because a bidder can relatively quickly take its case directly to the shareholders of a disloyal target board. The ballot box is less effective against EAT targets, but still there is a meaningful path to success, particularly in the (approximately) three months before the target's annual meeting. The ballot box, however, does not seem to be an effective safety valve against ESB targets.

We have presented theoretical reasons for predicting ESBs to have a strong antitakeover effect. This effect is likely to be of a different order of magnitude than other types of antitakeover charter and bylaw provisions. Not only does an ESB provide more delay and longer guaranteed tenure for an incumbent board, but, more importantly, it creates additional impediments by (i) eliminating any possibility that a buyer might emerge at a point in time that would not require delay, and (ii) requiring victories in two elections rather than one. Indeed, our analysis has shown that the antitakeover effects of an ESB are stronger not only than other existing antitakeover arrangements, but of hypothetical arrangements (currently not permissible) under which elections would be held only every two or three 
years. We now turn to test these theoretical arguments against the available empirical evidence.

\section{EMPIRICAL EVIDENCE}

The analysis of the preceding Part predicts that (1) ESBs make it more difficult for a hostile bidder to win control of the target's board through the ballot box mechanism; and (2) because the ballot box safety valve is rendered less effective when the target has an ESB, an ESB increases the likelihood that a target can remain independent when faced with a hostile takeover bid. We test these two hypotheses against the empirical evidence in Parts B, C, and D below and find strong support for both. In Parts $\mathrm{E}$ and $\mathrm{F}$ we examine whether ESBs provide countervailing benefits to takeover targets and find no evidence that they do. Part G concludes by estimating the aggregate losses caused to target shareholders by ESBs.

\section{A. Data Description}

Prior empirical studies of takeover defenses have found that these defenses have little or no effect on bid outcomes.120 These results are consistent with practitioner wisdom that takeover defenses matter only at the margin.121 However, these studies are problematic because they focus exclusively on the pill and fail to consider staggered boards and how they interact with the pill.122 As described in Part III.B, the pill by itself is not a potent defense, but the pill/staggered board combination has a substantial effect on bids. Furthermore, whether a target has a pill in place prior to a bid is also unimportant, given the ability of targets to adopt pills rapidly in

120. See, e.g., JAmil Aboumeri, Poison Pills And Shareholder Value, 1992-96 (1997) (finding that firms with pills are less likely to defeat hostile takeover bids than firms without pills); James A. Brickley, Jeffrey L. Coles \& Rory L. Terry, Outside Directors and the Adoption of Poison Pills, 35 J. FIN. ECON. 371 (1994) (finding that the proportion of outside directors does not influence the success rate of bids against firms with pills, but it does increase the likelihood that the target will be auctioned once a bid has been brought); Coates, supra note 58 (finding that pre-bid poison pills have no impact on bid outcomes); Michael Ryngaert, The Effect of Poison Pill Securities on Shareholder Wealth, $20 \mathrm{~J}$. FIN. ECON. 377, 407-08 (1988) (finding that 31\% of firms with pills remained independent, compared to $16 \%$ of firms without pills).

121. See supra notes 50-54 and accompanying text.

122. See, e.g., ABOUMERI, supra note 120, Brickley, Coles \& Terry, supra note 120; Ryngaert, supra note 120 . For a more detailed assessment of the existing empirical literature, see Bebchuk, Coates \& Subramanian, supra note 3. 
response to a bid.123

To correct these deficiencies, we constructed a new data set of hostile bids made against U.S. targets that were initiated and resolved between January 1996 and December 2000. The data set includes all the bids, 92 in number, for which there was data in the Thompson Financial Securities Data (formerly Securities Data Corporation) (SDC) database in November 1999 for the 1996-98 bids and in March 2001 for the 1999-2000 bids. Altogether our data set includes 92 bids. Specific charter and bylaw terms of each target were taken from the targets' filings with the SEC,124 to determine whether staggered boards are effective or can be evaded as described in Part III.C. Bidder and target SEC filings, as well as newspaper accounts, were used to verify bid outcomes and to classify bids as bust-up or stand-alone.125 Stock prices were obtained from the Center for Research in Securities Prices (CRSP) database. Summary data on target and bid characteristics and overall outcomes for this data set are presented in Table 2.

123. See Coates, supra note 58.

124. Specifically, each target's filings were found by searching for the target in the SEC's online EDGAR database, available at http://www.sec.gov/edaux/formlynx.htm. An exhibit list to the latest Form 10-K was reviewed to determine where to find the target's charter and bylaws, and relevant filings were obtained either from the target's online filings or, where they were unavailable, from Compact Disclosure (a private SEC filing service in CD-ROM and paper formats). Once obtained, charters and bylaws were analyzed as described in Coates, supra note 106.

125. Specifically, the target's filings were found, as described in the preceding note, and Schedules 14D-1 (or Schedules TO) were searched to see if the bidder made a tender offer as part of the hostile bid. If so, the "Background" section of the related offer to purchase (filed as an exhibit to the Schedule 14D-1) was read to determine if the bid was a bust-up bid and to confirm bidder identity, premium, deal size, and other data, and outcomes were determined by reviewing subsequent amendments to the Schedule 14D1. If no Schedule $14 \mathrm{D}-1$ was filed, Schedules $14 \mathrm{~A}$ were reviewed to see if the bidder conducted a proxy fight or consent solicitation as part of the bid; if so, similar procedures were followed. If not, Forms $8-\mathrm{K}$ and $10-\mathrm{Q}$, as well as news stories in Lexis/News, available at http:/ / www.lexis.com, were reviewed to confirm SDC data on the bid, its characteristic, and outcomes. 


\begin{tabular}{|c|c|c|c|}
\hline $\begin{array}{l}\% \text { of sample or } \\
\text { median (mean) }\end{array}$ & Total $(\mathrm{n}=92)$ & ESB $(n=45)$ & $\begin{array}{c}\text { No ESB } \\
(n=47)\end{array}$ \\
\hline \multirow{2}{*}{\multicolumn{4}{|c|}{$\begin{array}{l}\text { Target } \\
\text { Characteristics }\end{array}$}} \\
\hline & & & \\
\hline Size (\$ million) & $\$ 481(\$ 2,967)$ & $\$ 704(\$ 2,610)$ & $\$ 280(\$ 3,309)$ \\
\hline $\begin{array}{l}\text { Delaware } \\
\text { corporation }\end{array}$ & $51.1 \%$ & $57.8 \%$ & $44.7 \%$ \\
\hline \multicolumn{4}{|l|}{ Defenses } \\
\hline Staggered board & $60.9 \%$ & $100 \%$ & $23.4 \%$ \\
\hline $\begin{array}{l}\text { Effective } \\
\text { staggered board }\end{array}$ & $48.9 \%$ & - & - \\
\hline $\begin{array}{l}\text { Fair price } \\
\text { provision }\end{array}$ & $25.0 \%$ & $35.6 \%$ & $14.9 \%$ \\
\hline $\begin{array}{l}\text { Pre-bid poison } \\
\text { pill }\end{array}$ & $68.5 \%$ & $73.3 \%$ & $63.8 \%$ \\
\hline $\begin{array}{l}\text { Supermajority } \\
\text { vote provision }\end{array}$ & $30.4 \%$ & $37.8 \%$ & $23.4 \%$ \\
\hline \multicolumn{4}{|l|}{ Bid } \\
\hline Tender offer & $54.3 \%$ & $51.1 \%$ & $57.4 \%$ \\
\hline Proxy fight & $43.5 \%$ & $35.6 \%$ & $51.1 \%$ \\
\hline $\begin{array}{l}\text { Tender offer \& } \\
\text { proxy fight }\end{array}$ & $33.7 \%$ & $33.3 \%$ & $34.0 \%$ \\
\hline Bust-up bid & $19.6 \%$ & $24.4 \%$ & $14.9 \%$ \\
\hline Bear hug bid & $35.9 \%$ & $46.7 \%$ & $25.5 \%$ \\
\hline $\begin{array}{l}\text { Final bid } \\
\text { premium }\end{array}$ & $37.2 \%(43.2 \%)$ & $38.5 \%(44.1 \%)$ & $35.0 \%(42.4 \%)$ \\
\hline
\end{tabular}

Table 2 shows that $61 \%$ of bids (56 bids) were brought against targets with staggered boards. Of those, eleven SBs were not "effective" as takeover defenses in the sense discussed above. Thus, of the ninety-two bids, $49 \%$ were brought against targets with ESBs. Pre-bid poison pills are present at nearly $70 \%$ of targets; moreover, all targets in our sample that did not have pills at the time of the bid announcement put in "morning after" pills as the first step toward resistance or at least to gain time and bargaining power against the bidder.126

126. E.g., Bill Atkinson, Glen Burnie Bancorp Tries to Resist Hostile Takeover, BALT. Sun (Feb. 18, 1998), at 3C (Glen Burnie adopts pill in response to hostile bid); Urocor 


\section{B. Viability of the Ballot Box Mechanism}

In Part III we argued that the ballot box mechanism is not an effective route against ESB targets. In this Part we test this prediction empirically by examining the outcomes of the proxy contests in our data set. Note that the mere existence of proxy solicitations against ESB targets does not necessarily mean that proxy contests are a viable route against such targets. Proxy contests could be launched for several reasons independent of their effectiveness as a way of taking over the target-for example, to complement a concurrent public relations campaign intended to put market pressure on the board or to show the bidder's seriousness. The best test to assess the effectiveness of the proxy contest route is to examine whether there are cases in which a target is taken over against the wishes of the incumbent board due to the presence of this route.

Note that we define these "ballot box victories" broadly, to include not only situations in which the bidder actually wins control over the board but also situations in which target management capitulates and agree to an acquisition a short time before the shareholder vote. The reason is that once a bidder is fairly certain to gain control of the board in an imminent vote, managers might well choose to make a graceful exit, possibly extracting some benefit for themselves, which would not be possible after the vote has occurred. A bidder's gaining control over the board can become fairly certain only close in time to the relevant vote, because until then there is still some chance that a change in circumstances will make the bidder's offer less attractive or that the bidder will withdraw its bid (as happened in Circon).

\section{Against ESB targets.}

Applying our test, we find not a single ballot box victory against the ESB targets in our sample. In fact, only one proxy fight against an ESB (Circon) went to a shareholder vote for the first time. In the Circon situation, the hostile bidder (U.S. Surgical) was itself taken over and withdrew five months before the second shareholder vote. Thus, Circon illustrates why target managers faced with an attractive acquisition proposal do not have to assume that the bidder will gain control ultimately - the ESB gives the target

Rejects Dianon's Acquisition Advances, MedicAl Industry TODAY, Aug. 21, 1998, available at http://www.lexis.com (Urocor adopted pill after it received hostile bid); AcmeCleveland Corp. Form 8-A/A (filed June 3, 1996), available at http://www.sec.gov/Archives/edgar/2066/0000950152-96-002745.txt (referring to a rights plan adoption on March 11, 1996, four days after Danaher Corp. launched its bid for Acme-Cleveland); Hall, Rose \& Subramanian, supra note 33, at 5 (reporting that Circon installed a poison pill just days after U.S. Surgical launched its hostile bid). 
substantial time, and during that time unforeseen events may intervene to allow the target to remain independent. Thus, in our sample period, no bidder has come closer than five months to running the second proxy contest necessary for a ballot box victory.

It might be argued that we should include instances where a bidder wins a single proxy contest-such as the Circon situation-as "ballot box victories," because the election of a single slate of insurgent directors may put sufficient pressure on the target's incumbent board members so that they concede. Looking outside of our sample period, Weyerhaeuser's recent and well-publicized hostile bid for Willamette provides a good illustration of this point: After Weyerhaeuser won one-third of the seats on Willamette's board in July 2001, the two companies negotiated a friendly sale in January 2002.127 However, in three other instances in which a hostile bidder won a first proxy contest against an ESB-Moore's hostile bid for Wallace Computer, Carson Pirie Scott's bid for Younkers, and Boston Bank of Commerce's bid for Carver Bancorp - the initial bidder did not eventually win control of the target. Thus out of the five instances in recent memory in which the bidder won a first proxy contest against an ESB, only in one case (Weyerhaeuser) was the initial bidder eventually successful.

In any particular contest, various factors will determine how much "market" pressure is brought to bear on incumbents, for example: the presence of precatory shareholder resolutions opposing defenses or proposing sale; the number and fraction of independent directors on the target's board; the percentage of shareholders who have tendered into the bidder's offer; the effectiveness of the bidder's public relation campaign; the presence of activist institutional investors. A bidder's winning one proxy contest against an ESB - which would be a clear indication of shareholders' support for the offer-is certainly a factor that would add to the pressure on incumbents. However, the critical point is that, as a legal matter, a victory in one election, or the manifestation of shareholder support for the offer in other ways, does not preclude the target's board from holding firm until the second election if it chooses to-and thus does not in any way guarantee success for the bidder. The examples noted above of bidders winning one election but not ultimately gaining control provide a vivid illustration of this point.

In sum, we are unaware of any instance, either during the sample period or outside it, in which a bidder successfully gained control of the target using the ballot box. This has not been the case, however, with respect to non-ESB targets.

127 See Willamette Industries Inc.: Weyerhaeuser Slate Gains Seats on Company's Board, WALL ST. J. (July 17, 2001) at C13; Jim Carlton \& Robin Sidel, Willamette Agrees to be Bought by Weyerhaeuser, WALL ST. J. (Jan. 22, 2002) at A3. 


\section{Against non-ESB targets.}

In contrast, the ballot box mechanism seems to be a viable mechanism against non-ESB targets. In March 1999, for example, Philips launched a proxy contest against VLSI after VLSI rejected its unsolicited \$17-per-share tender offer. VLSI was an NMT target, so Philips immediately began soliciting proxies to act by written consent.128 In May 1999, Philips withdrew its proxy solicitation when VLSI agreed to a negotiated sale for $\$ 21$ per share.

Similarly, noted shareholder activist Guy Wyser-Pratte launched a proxy contest against Rexene in April 1997, in order to replace the incumbent board with directors who would accept Huntsman's hostile bid. The special shareholders' meeting was scheduled for May twenty-second; on May twentieth, Rexene entered into talks with Huntsman and negotiated the sale.

A third example of a ballot box victory against a target without an ESB is the Fant Industries bid for HEI. In this case, Fant actually went through with its proxy contest and won four seats on the target's board in August 1998. Fant then replaced the CEO and consummated its hostile bid.

Taken together, these findings support the theoretical arguments put forward in Part III, that the ballot box route is an ineffective route against an ESB but an effective route against a non-ESB. In fact, winning through the ballot box mechanism against an ESB seems very difficult indeed. As emphasized earlier, the argument does not imply that hostile bidders will never be successful against ESBs. But the important point is that, if the incumbents decide to resist, the ability of the bidder to oust them remains extremely limited.

\section{Remaining Independent in the Short-run}

If the ballot box route is not an effective safety valve against an ESB, we would expect that targets will have greater ability to remain independent with an ESB.129 This Part examines bid outcomes in the short-run, defined as the first nine months after the hostile bid announcement. In the next Part, we examine target independence in the longer run, defined as the thirty-month period after bid announcement.

128. See Steven Lipin, Philips Electronics Readies Proxy Fight if VLSI Refuses to Negotiate on Offer, WALL ST. J., Mar. 3, 1999, at B6 ("The biggest chink [in VLSI's takeover defenses] is that any entity that owns VLSI shares can effectively remove the board by canvassing shareholders via a so-called consent solicitation at any time.").

129. Cf. Robert H. Mnookin \& Lewis Kornhauser, Bargaining in the Shadow of the Law: The Case of Divorce, 88 YALE L. J. 950, 951 (1979) (demonstrating how the "shadow of the law" provides endowments that influence outcomes). 


\section{General findings.}

Figure 3 shows the short-run outcomes of all bids against ESBs $(n=45)$ and non-ESBs $(n=47)$ between 1996 and 2000. For purposes of the analysis the short-run is defined as nine months after the hostile bid is brought, though in Part IV.C.4 we show that the results do not change in any significant way if we use six months or twelve months after bid announcement as the timeframe for analysis.

Figure 3: Bid Outcomes in the Short-run

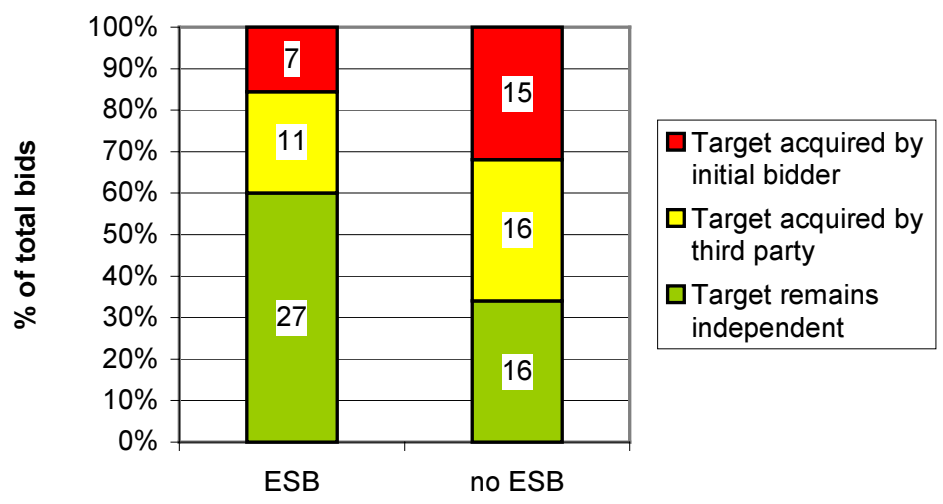

Figure 3 reveals a striking difference in success rates depending on the target's defenses: $60 \%$ of ESB targets remained independent against a hostile bid, compared to $34 \%$ of non-ESB targets. The difference is made up of fewer sales to initial bidders (16\% of ESB targets versus $32 \%$ of non-ESB targets) and fewer sales to white knights ( $24 \%$ of ESB targets versus $34 \%$ of non-ESB targets). These results are consistent with our findings from Part IV.B, which show that proxy contests are an ineffective route against ESBs. These results also call into question the findings from prior studies that purport to show that takeover defenses generally have no impact on bid outcomes.

\section{Controlling for other parameters.}

To control for factors other than ESBs that could plausibly influence the outcome of takeover contests, we have used multivariate regression analysis. The control factors used in this analysis include the target's other takeover defenses (dual class stock, fair price provision, pre-bid poison pill, supermajority voting provision), bid features (proxy fight, bear hug bid, tender offer, bust-up bid), and control variables (natural log of deal size, bid premium, and whether target is a Delaware firm).

This analysis shows that ESBs continue to have the predicted impact on outcomes and target independence rates when we control for these other 
factors. 130 Using the method of recycled predictions, the results indicate that ESBs nearly double the average target's odds of remaining independent, from $34 \%$ to $61 \%$, cut the odds of a bidder completing its bid from $34 \%$ to $14 \%$, and cut the odds that the average target in our sample will be forced into selling to a white knight, from $32 \%$ to $25 \% .131$ These results are consistent with the basic findings presented in Figure 3.

\section{Selection problems.}

It might be suggested that ESBs have another effect on remaining independent that is not captured by the analysis thus far. So far we have taken as given that a bid has been made. But whether a bid is made might depend on defenses-specifically, the presence of an ESB might discourage some bids. Thus, the bids that are made for ESBs might be a subset of bids that would have been made otherwise; indeed, this subset might be skewed toward buyers that are relatively more determined and motivated.

We agree that such a selection might be taking place.132 However, its presence would imply that the effect of an ESB on the likelihood of remaining independent is even larger than suggested by our already strong results. Here we show that an ESB increases the odds of independence by defeating bids that occur; a selection effect would imply that ESBs also increase the odds of independence by discouraging offers from being made in the first place.

In addition to this bidder-side selection effect, there is a potential targetside selection effect: It might be the case that targets with ESBs are different in some underlying features that lead to the adoption of the ESB in the first place. According to this view, it would be these underlying features, and not the presence of the ESB, that are responsible for the increased likelihood of independence. However, this potential target-side endogeneity problem is mitigated considerably by the fact that that most of the targets in our data set existed prior to 1990 . For such mature companies, ESB installation could have occurred only before 1990, because (for reasons discussed in Part II.D) a charter amendment to install a staggered board became extremely difficult after 1990. So whether these targets had ESBs in the mid to late 1990s

130. A detailed presentation of the model specification and results is provided in our working paper, Bebchuk, Coates \& Subramanian, supra note 3.

131. The method of recycled predictions compares the likelihood of each outcome in two hypothetical scenarios: one in which all targets have ESBs and one in which all targets do not have ESBs.

132. But cf. supra notes 50-54 and accompanying text (finding that practitioners seem to underestimate the antitakeover power of staggered boards, which in turn suggests that bid deterrence might be minimal). 
depended on actions taken in the 1980s or even earlier. Different decisions in this earlier era are unlikely to translate into large enough differences between the ESB and non-ESB targets in the 1990s to account for the results we get.133

\section{Defining the short-run.}

While the difference in target independence rates documented in Figure 3 also appears when we examine a six-month window after bid announcement (73\% independence rate among ESB targets compared to a $47 \%$ independence rate among non-ESB targets), we find that many bid outcomes in our sample are still uncertain after six months. By nine months, however, we find that virtually all of the dust has settled on the initial hostile bids. In fact we find that only two bid outcomes in our data set changed in the nine to twelve month window: ITT fended off Hilton and sold itself to Starwood in November 1997 (bid was announced in January 1997), and Healthdyne fended off Invacare and sold it sold itself to Respironics, also in November 1997 (original bid also announced in January 1997). Both of these targets did not have staggered boards, so the results are more pronounced in favor of ESB target independence when we use twelve months for our short-run window: 30\% independence rate for non-ESB targets (14 out of 47), compared to the same $60 \%$ independence rate for ESB targets (27 out of 45 ).

Nevertheless, we use a nine-month window instead of a twelve-month window for our short-run analysis because wealth effects, which we examine in Parts IV.E through IV.G, become increasingly problematic to calculate as the time frame for analysis gets longer. ${ }^{134}$ Still, to alleviate concerns that we are missing part of the story by looking only at short-run outcomes, we examine long-run bid outcomes in the next Part.

133. In prior work one of us has argued that selection effects may be the cause for Robert Daines' finding that Delaware firms have higher Tobin's $Q$ than non-Delaware firms. See Bebchuk \& Ferrell, supra note 46; Robert Daines, Does Delaware Law Improve Firm Value?, 62 J. FIN. ECON. 525 (2001). The critical difference between the reincorporation decision and the staggered board decision is that reincorporations continued to be a viable option for managers throughout the 1990s, see Subramanian, supra note 30 (manuscript at 23 tbl. 1) (reporting 373 midstream reincorporations among U.S. public companies in the 1990s), while the ability to adopt a staggered board was effectively unavailable to managers after 1990. See Klausner, supra note 42, at 3-4 ("This decline [in staggered board proposals] reflects management realization that there is no point in even asking shareholders to support a classified board."). In short, the staggered board decision, unlike the reincorporation decision, was effectively frozen as of 1990; therefore it seems reasonable to take ESB incidence as exogenous to events that occurred in our 1996-2000 sample period.

134. See sources cites infra note 142. 


\section{Remaining Independent in the Longer-run}

In Part II.E we described the conventional wisdom among M\&A practitioners that a target, once put into play by a hostile bidder, will be sold either to the hostile bidder or to a white knight. The empirical evidence presented in Part IV.C suggests that this conventional wisdom is incorrect, at least in the short run, if the target has an ESB. Nevertheless, it might still be argued that ESB targets are eventually sold once a bid is made, but the outcome takes longer to play out because of the delay imposed on the initial bidder by the ESB. In this Part we examine whether targets remain independent in the longer run, defined as the thirty-month window after bid announcement.

Figure 4 presents basic statistics on the status of the targets in our sample thirty months after the initial hostile bid is announced, again divided between ESB targets $(n=45)$ and non-ESB targets $(n=47) .135$

Figure 4: Bid Outcomes in the Long-run

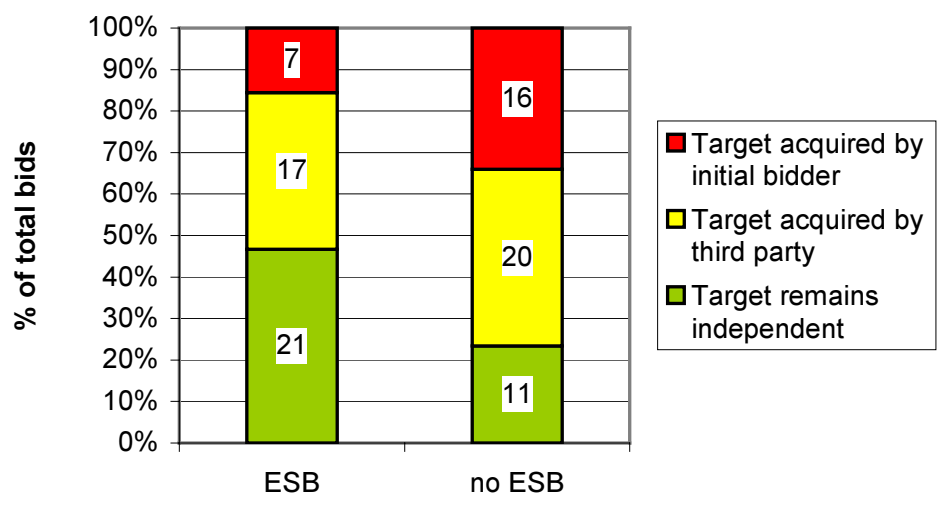

Not surprisingly, the independence rate has decreased for all targets relative to Figure 3: The number of independent ESB targets has declined from 27 to 21, and the number of independent non-ESB targets has declined from 16 to 11 in this longer timeframe. The basic finding that ESB targets are much more likely to remain independent remains, and in fact becomes even more pronounced relative to the short-run analysis: 47\% of ESB targets remain independent thirty months after the initial hostile bid is launched, compared to only $23 \%$ of non-ESB targets. As in the short run, the difference is made up of fewer sales to initial bidders (16\% of ESB targets versus $34 \%$ of non-ESB targets) and fewer sales to other bidders (38\% of ESB targets versus

135. While it is conceivable that a target could have changed from a non-ESB target to an ESB target (or vice versa) between the announcement of the hostile bid and thirty months later, none of the targets in our sample did so. 
$43 \%$ of non-ESB targets). These results continue to hold in a multivariate regression that controls for other relevant factors in the same way that has been used for testing with respect to remaining independent in the short run. ${ }^{136}$

\section{E. The Cost of Remaining Independent}

In the prior two parts we showed that a target can remain independent far more often when it has an ESB, both in the short run and in the longer term. In this section we show that target shareholders generally suffer when the target remains independent-that is, remaining independent makes the shareholders of hostile bid targets worse off compared with the scenario in which the bid would have been successful. It might be argued that incumbents retain independence in those instances in which they would be able to achieve the same or higher value-creating gains on their own, either by achieving stand-alone operational improvements or by providing information to the marketplace that corrects an underpricing of their firm. The remainder of this section demonstrates that this hypothesis is, on average, not correct.

As a starting point, Table 3 provides aggregate statistics on average (mean) shareholder returns by bid outcome.137 These calculations include the premiums achieved through subsequent completed bids against targets that remain independent, in order to give full credit for management plans to sell to a "better" bidder than the initial hostile bidder. The calculations also assume that cash received at any time (for example, at the completion of a bid) is reinvested at the risk-free rate, assumed to be $6 \% .138$

136. See Bebchuk, Coates \& Subramanian, supra note 3 .

137. We plan to estimate in subsequent work abnormal returns rather than absolute returns, though we do not believe that this adjustment will change our overall conclusions. The bids in our sample are distributed uniformly over the sample period, and the market overall moved fairly consistently in an upward direction during this time.

138. Note that using the risk-free rate rather than a market return biases our results in favor of ESBs: shareholders in non-ESB targets generally receive cash sooner than shareholders in ESB targets; presumably these non-ESB shareholders have opportunities to re-invest this cash at higher than the risk-free rate. We nevertheless use a risk-free reinvestment rate assumption as a conservative estimate. 


\begin{tabular}{|c|c|c|c|c|c|c|}
\hline $\begin{array}{l}\text { Bid } \\
\text { Outcome }\end{array}$ & ESB & $\begin{array}{l}\text { No } \\
\text { ESB }\end{array}$ & Total & ESB & $\begin{array}{l}\text { No } \\
\text { ESB }\end{array}$ & Total \\
\hline $\begin{array}{l}\text { Remained } \\
\text { Independent }\end{array}$ & $15.6 \%$ & $22.9 \%$ & $18.2 \%$ & $25.3 \%$ & $24.4 \%$ & $25.0 \%$ \\
\hline $\begin{array}{l}\text { Sold to } \\
\text { Other Bidder }\end{array}$ & $58.1 \%$ & $63.3 \%$ & $61.1 \%$ & $83.1 \%$ & $91.2 \%$ & $87.3 \%$ \\
\hline $\begin{array}{l}\text { Sold to } \\
\text { Initial Bidder }\end{array}$ & $52.5 \%$ & $43.9 \%$ & $46.7 \%$ & $73.0 \%$ & $65.3 \%$ & $67.6 \%$ \\
\hline $\begin{array}{l}\text { Average } \\
\text { Return in } \\
\text { Case of Sale }\end{array}$ & $56.0 \%$ & $53.6 \%$ & $54.5 \%$ & $80.1 \%$ & $79.3 \%$ & $79.7 \%$ \\
\hline $\begin{array}{l}\text { Average } \\
\text { Cost of } \\
\text { Remaining } \\
\text { Independent }\end{array}$ & $40.4 \%$ & $30.7 \%$ & $36.3 \%$ & $54.8 \%$ & $54.9 \%$ & $54.7 \%$ \\
\hline
\end{tabular}

Table 3 shows large statistical differences in shareholder returns across outcomes. In the short run, targets that are sold to an initial bidder achieve nine-month returns that are $29 \%$ higher than targets that remain independent, and targets that are sold to a white knight achieve an additional $14 \%$ beyond that. Combining these two sale outcomes, ninemonth returns in the case of a sale are 55\%. Compared against the 18\% returns from remaining independent, this result suggests a $36 \%$ cost of remaining independent in the short run.

In the long run, targets that are sold to an initial bidder achieve thirtymonth returns that are $43 \%$ higher than targets that remain independent; and targets that are sold to another bidder achieve an additional $20 \%$. Combining the two sale outcomes, thirty-month returns in the case of a sale are $80 \%$ on average, compared to $25 \%$ returns for targets that remain independent, yielding a $55 \%$ cost of remaining independent in the longer term.

In short, the large and statistically significant differences between outcome categories indicate that the shareholders of targets that remained independent were made substantially worse off by the defeat of the hostile bid compared with the scenario in which the bid would have been accepted. This result continues to hold when we control for other factors that might influence shareholder returns, in both the short run (9 months) and the long run (30 months). ${ }^{139}$

139. See Bebchuk, Coates \& Subramanian, supra note 3. 


\section{F. Do ESBs Produce Offsetting Benefits by Increasing Premiums?}

So far we have demonstrated that an ESB allows a target to remain independent more often against a hostile bid and that remaining independent is generally rather bad for target shareholders. Against these costs, however, ESBs might provide countervailing benefits for target shareholders. One such benefit might be increased bargaining power for target managers, which in turn would raise the premium in the event of an acquisition. If true, this theory would be consistent with some poison pill studies showing that higher premiums are correlated with whether the target has adopted a poison pill prior to a hostile bid or friendly merger.140

In this Part we consider the theory that ESBs might create value for target shareholders by providing target managers with greater bargaining power ("bargaining power hypothesis"). As a starting point, Table 2 shows that the average final bid that a hostile bidder makes for an ESB target is $44.1 \%$ over the pre-bid market price, compared with $42.4 \%$ average final bid premium for non-ESB targets. Focusing only on successful bids, we find that the final acquisition premium is $54.4 \%$ for targets with ESBs and $49.6 \%$ for targets without ESBs. While this 5\% difference in favor of ESBs provides some marginal evidence in favor of the bargaining power hypothesis, a statistical test indicates that it is not statistically significant $(t=0.76)$. An ordinary least squares regression, with final bid premium as the dependent variable, and controlling for the other relevant factors, similarly indicates that the coefficient for ESB is not statistically significant in predicting bid premium $(\mathrm{t}=0.74) .141$

Given the lack of any significant differences in premiums, it is unsurprising that shareholder returns are not statistically different between ESB and non-ESB targets that are sold. Examining the columns of Table 3, we find that short-run returns for targets that are sold are $56.0 \%$ when there is an ESB, and $53.6 \%$ when there is not. In the long-run, returns for ESB targets that are sold are $80.1 \%$, compared to $79.3 \%$ for non-ESB targets. Neither of these differences is statistically significant. While these results do not rule out the possibility that premiums and returns against ESB targets might be higher (and statistically significant) if we were to examine a larger

140. See AbOumeri, supra note 120; J.P. Morgan \& CO., POISON Pills AND ACQUISITION PREMIUMS (1995) (on file with authors). But see Coates, supra note 58 (arguing that pre-bid pills should be irrelevant due to the "shadow pill").

141. For more details on this regression, which uses the same independent variables as the regressions whose results were reported earlier, see Bebchuk, Coates \& Subramanian, supra note 3. Alternative specifications (including using the log of deal premium as the dependent variable) yield similar results. 
sample, the data do suggest that the differences are not of the order of magnitude that would be necessary to offset the large differences in the likelihood of achieving these premiums.

In short, ESBs do not seem to provide sufficiently large countervailing benefits for shareholders of hostile bid targets, in the form of higher deal premiums, to offset the substantially lower likelihood of being acquired. In fact, the evidence is not sufficient even to conclude that there is any positive effect at all of ESBs on deal premiums, though we cannot reject this possibility with our small-sample analysis. However, even if future research were to conclude that ESBs do yield higher premiums for target shareholders in deals that are successful, ESBs do not seem to have a major impact on premiums of the kind that would be necessary to outweigh their negative effects on bid outcomes.

\section{G. Overall Effect on Target Shareholder Value}

To summarize the argument thus far, we have shown that (1) ESBs substantially increase the likelihood of remaining independent; (2) remaining independent is quite costly compared with accepting the bid; and (3) ESBs do not provide sufficient countervailing benefits (and may produce no benefits at all) in terms of increasing the premium in the event of an acquisition. We now aggregate these various elements and quantify them in order to calculate the overall effect of ESBs on target shareholder value.

\section{General findings.}

The effect of ESBs on shareholder wealth can be disaggregated into two pieces: first, the increased likelihood of remaining independent that an ESB provides; and second, the cost associated with remaining independent. We have shown so far that both pieces are substantial: Figure 3 shows that the likelihood of remaining independent is $26 \%$ higher for ESB targets; Table 3 shows that the short-run cost of remaining independent is $36 \%$. This Part quantifies this effect more carefully.

As a starting point we examine total shareholder returns, irrespective of bid outcome, for ESB and non-ESB targets. Shareholders in the ESB targets in our sample achieved $31.8 \%$ returns in the nine months after a hostile bid was announced, compared to $43.4 \%$ returns for the shareholders in non-ESB targets, representing an $\mathbf{1 1 . 6 \%}$ difference. As noted above, this difference is

driven entirely by the difference in success rates for the hostile bidders between the two samples. 


\section{Controlling for other parameters.}

Of course, to make a more accurate assessment of the overall effect of having an ESB, it is necessary to control for other factors that might have an independent impact on bid outcomes. Our samples of ESB targets and nonESB targets may have different characteristics that may lead us to misestimate the wealth effects of ESBs when we look only at simple averages. To take an extreme example, if all ESB targets also had fair price provisions and all non-ESB targets did not, and if fair price provisions had an independent impact on either bid outcomes or bid returns, then some of the effect that we attribute to ESBs should in fact be attributed to the fair price provisions.

If a bid is made, expected returns to shareholders equal:

Prob (Acquisition by Initial Bidder) * E [Return STIB]

+ Prob (Acquisition by White Knight) * E [Return sTwK]

+ Prob (Independence) * E [ Return conditional on no acquisition]

Table 4 synthesizes the results reported earlier to display the differences between ESBs and non-ESBs in the various elements that make up expected returns: 
Table 4: Overall Effect of ESBs on Target Shareholder Value

Prediction Prediction Difference

for all for all (ESB - no

targets with targets ESB)

ESBs without

ESBs

\begin{tabular}{lccc}
\hline $\begin{array}{l}\text { Prob } \\
\text { (Acquisition } \\
\text { by Initial }\end{array}$ & $13.8 \%$ & $34.0 \%$ & $-20.2 \%$ \\
$\begin{array}{l}\text { Bidder) } \\
\text { E }\end{array}$ & & & \\
E [Return STIB] & $46.3 \%$ & $46.8 \%$ & $-0.5 \%$ \\
\hline + Prob & $25.0 \%$ & $32.0 \%$ & $-7.0 \%$ \\
\hline
\end{tabular}

(Acquisition

by White

Knight) *

$\begin{array}{llll}\mathrm{E} & 60.3 \% & 60.8 \% & -0.5 \%\end{array}$

[ReturnstwK]

$+$

Prob

$61.2 \%$

$34.0 \%$

$27.2 \%$

(Independenc

e) *

E [Nine- $\quad 17.9 \% \quad 18.4 \% \quad-0.5 \%$

Month

Return]

\begin{tabular}{llll} 
Nine-month & $32.4 \%$ & $41.6 \%$ & $-9.2 \%$ \\
target & & & \\
shareholder & & & \\
returns & & \\
(conditional & & & \\
on a bid & & & \\
being made) & & & \\
\hline
\end{tabular}

Notes: Event window is one month prior to bid announcement to nine months after bid announcement, and includes returns from subsequent acquisitions by other bidders.

Probabilities and returns are calculated using the method of recycled predictions, and control for other factors, as described in Part IV.C.2, that may influence bid outcomes. Using simple means instead yields similar results.

Model assumes that cash received at any time (e.g., at the completion of a bid) is reinvested at the risk-free rate (assumed to be 6\%).

Table 4 shows no statistically significant differences in the returns to target shareholders by type of defense, conditional on a particular outcome 
being realized. However, the dramatic differences in likelihood of outcomes yield substantial differences in the expected returns to target shareholders. Using the window from one month prior to bid announcement to nine months after bid announcement, the expected returns to target shareholders when an ESB is not present are $41.6 \%$, compared to $32.4 \%$ when an ESB is present, a $9.2 \%$ difference in returns.

We also estimated the difference in returns using the method of recycled predictions. We ran a robust regression to predict nine-month returns, including ESB as a dummy variable in the model and controlling for variables that also might influence bid outcomes and bid returns.142 We then predicted returns in two scenarios: one in which all ninety-two targets have ESBs and one in which none of the ninety-two targets have ESBs. The results of this analysis indicate that nine-month returns are 32.2\% for our set of ESB targets and $40.4 \%$ for our set of non-ESB targets, an $8.2 \%$ difference.

Taken together, our calculations suggest that an ESB reduces target shareholder returns on the order of $8-10 \%$ in the nine months after a hostile bid is launched. This finding is consistent with studies showing that the Massachusetts staggered board statute reduced the value of companies incorporated in Massachusetts. ${ }^{143}$

It is worth noting that the losses to shareholders we have estimated in this Part are only those that are produced when bids are made. Because ESBs greatly enhance the power of incumbents to resist hostile bids, they substantially curtail the threat that such bids pose to incumbents. As a

142. See Bebchuk, Coates, and Subramanian, supra note 3. The coefficient for ESB is negative (-0.08), consistent with our theory, but the standard error is sufficiently large (0.10) that the variable is not statistically significant at $95 \%$ confidence. At least part of the difficulty arises from the high variability of returns that arises from our relatively long event window. Other commentators have noted the difficulties in examining stock returns over long event windows. See, e.g., Brad M. Barber \& John D. Lyon, Detecting Long-Run Abnormal Stock Returns: The Empirical Power and Specification of Test Statistics, 43 J. FIN. ECON. 341, 342-43 (1997) (finding that long-run tests are misspecified and identifying new listing bias, rebalancing bias, and skewness bias as reasons); S.P. Kothari \& Jerold B. Warner, Measuring Long-Horizon Security Price Performance, 43 J. FIN. ECON. 301, 301 \& 337 (1997) (finding that tests of multi-year abnormal returns around firm-specific events are "severely misspecified" and concluding that "the interpretation of long-horizon tests requires extreme caution"); Craig E. Lefanowicz \& John R. Robinson, Multiple Bids, Management Opposition, and the Market for Corporate Control, 35 FIN. REV. 109 (2000) (excluding acquisitions that took more than 250 days to complete "because of the problems... in cumulating abnormal stock returns over long event windows").

143. See L. Mick Swartz, The Massachusetts Classified Board Law, 22 J. ECON. \& FIN. 29 (1998); Robert Daines, Do Staggered Boards Affect Firm Value? Takeover Defenses After the Poison Pill (working paper, on file with authors). 
result, ESBs might also produce additional costs in terms of adverse ex ante effects on managers' behavior and performance. Studying and estimating these ex ante effects is an important issue left for future empirical research.

\section{DID SHAREHOLDERS CONSENT?}

We have thus far shown that ESBs are by far the most important takeover defense mechanism in the market for corporate control and that they have a substantial negative impact on the wealth of target shareholders. Defenders of ESBs might nevertheless suggest that, whether ESBs are good or bad for shareholders, ESBs received shareholder approval. An SB must be specified in the charter in order to become an ESB, and a charter provision must be specified either at the IPO stage (at which time shareholders would have implicitly accepted the provision by purchasing the IPO shares) or through midstream charter amendment (which requires a shareholder vote). In either case, goes the argument, shareholders would have consented to the ESB.

In this Part, however, we argue that even though all ESBs received formal approval from shareholders, the potency of ESBs as an antitakeover device was never genuinely consented to by the shareholders of the large majority of companies that now have ESBs. Thus, the effects of ESBs that we document were largely unintended by target shareholders when provisions establishing staggered boards were included in corporate charters. To put it more starkly, our argument is that, in most ESB companies, shareholders could not have reasonably expected, when provisions establishing staggered boards were adopted, that these provisions would subsequently gain the powerful antitakeover significance that we have documented. ${ }^{144}$

\section{A. A Brief History of Takeovers and Staggered Boards: From Inco to Moran to Time}

Before the invention of the poison pill, the staggered board was fairly innocuous as a takeover defense. As described in Part III.A, a staggered

144. The "mid-stream problem" resulting from the adoption of charter provisions prior to the developments in takeover law that gave them substantial antitakeover significance was highlighted in Bebchuk \& Ferrell, supra note 46 . We provide below empirical evidence of the very substantial magnitude of the problem as far as charter provisions establishing staggered boards are concerned. We believe the picture is similar with respect to other kinds of antitakeover charter provisions. See also Lucian Bebchuk \& Assaf Hamdani, Optimal Defaults for Corporate Law Evolution, Nw. U. L. REV. (forthcoming 2002) (discussing the problem of mid-stream changes in takeover law); Sharon Hannes, The Determinants and Consequences of Corporate Stagnation: Discussion and Reform Proposal (2001) (working paper, on file with authors) (discussing the problem of "stagnation" of corporate arrangements). 
board could not block a bidder from acquiring a control block and creating a situation in which a board control shift would be inevitable. Given this inevitability, a lame-duck incumbent board would resign rather than wait through two elections. As a result, target boards were unable to use staggered boards to block beneficial acquisitions of a controlling block.145

The pre-pill era can itself be divided into two distinct periods. Before Inco's successful tender offer for ESB in 1974, hostile tender offers were uncommon, particularly for large, established targets.146 Thus it is unlikely that the staggered boards that were adopted prior to 1974 were adopted for takeover defense reasons.147 Even after hostile bids became part of the acceptable toolkit in 1974, neither shareholders nor managers could foresee the advent of the pill, which would cut off the tender offer route and force shareholders to depend on the ballot box as a safety valve against disloyal managers. As a result, although true motives are difficult to discern, managers typically proposed staggered boards before 1984 primarily for board stability reasons and shareholders approved staggered boards in that period primarily for board independence reasons, as described in Part II.C.1.

From our sample of Investor Responsibility Research Center (IRRC) companies, ${ }^{148}$ Figure 5 below shows that $6 \%$ of staggered boards were installed pre-Inco, and another $17 \%$ were installed before Moran validated the poison pill. Thus, roughly one-quarter of staggered boards in place today were approved in a dramatically different takeover environment than presently exists. ${ }^{149}$

145. In fact, during this period, even deals that were not beneficial might have succeeded. During the era before the poison pill, target shareholders ran the risk that if they did not tender, they would be squeezed out in a back-end squeeze-out (at a lower price) if the bidder won. See supra text accompanying notes 84-87. In fact, acquirers during this era exploited this possibility through two-tier tender offers, cascading tender offers, and other coercive tender offer structures. See Guhan Subramanian, A New Takeover Defense Mechanism: Using an Equal Treatment Agreement as an Alternative to the Poison Pill, 23 DEL. J. CORP. L. 375, 387-389 (1998).

146. See Bruce WASSERStein, Big Deal 73 (1998). Morgan Stanley's willingness to represent Inco in its bid gave hostile bids a new respectability. See id.

147. It is possible that some pre-Inco SBs were adopted to defend against pure proxy fights, of the sort that were not uncommon in the 1950s. But proxy fights in that era were rarely coupled with hostile takeover bids, such that the dynamics and likely effects of those fights on target shareholder returns were vastly different than proxy fights designed to facilitate takeover bids.

148. Described in Part II.B, supra.

149. Weighting by sales or net assets yields virtually the same breakdown of SB timing. 
Figure 5: Staggered Board Incidence by Era

$100 \%=712$ companies

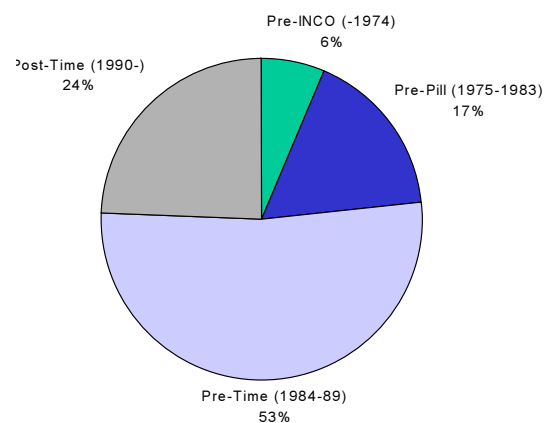

Moreover, while Moran changed the landscape, it initially appeared to change it only slightly. After Moran, a bidder would have to use the ballot box to gain control of the board, but an alternative, viable route to bid success appeared to remain over and beyond the proxy mechanism because of the qualified right for target boards to resist a hostile offer. The line of cases beginning with Moran and proceeding through AC Acquisitions Corp.,150 Revlon,151 Interco,152 and Macmillan,153 all demonstrated that the right to resist a hostile bid was not absolute, and suggested that Delaware courts would continue to interpret a target board's fiduciary duties so as to enable hostile bids to succeed even without a proxy fight.

Figure 5 shows that $53 \%$ of staggered boards were installed after Moran but before Time. During this period, managers were no doubt motivated by the threat of hostile takeover in proposing staggered boards. Shareholders, meanwhile, generally approved staggered boards during this period because a hostile bidder still had a viable route against a disloyal target board. When a bidder made an offer that shareholders wanted, the case law suggested that the Delaware courts would force a redemption of the pill if the target board did not redeem the pill on its own.

Time, of course, seemed to change all that. To many observers, Time transformed what was a highly qualified right to use the pill into a seemingly absolute right to "Just Say No." Cases such as Wallace Computer have shown that courts will allow incumbents to retain a pill and resist a

150. AC Acquisitions Corp. v. Anderson, Clayton \& Co., 519 A.2d 103 (Del. Ch. 1986) (enjoining defensive recapitalization under Unocal).

151. Revlon v. MacAndrews \& Forbes Holdings, 506 A. 2d 173 (Del. 1986) (enjoining asset lockup and other defensive actions under Unocal).

152. City Capital Assocs. v. Interco, Inc., 551 A.2d 787 (Del. Ch. 1988) (enjoining recapitalization and mandating redemption of pill under Unocal).

153. Mills Acquisition Co. v. Macmillan, Inc., 559 A.2d 1261 (Del. 1989) (enjoining management buyout, following earlier decision to enjoin defensive recapitalization). 
hostile bid indefinitely.154 Figure 5 shows that only a quarter of staggered boards appeared post-Time, in the modern pill era. Even this figure overstates the number of truly new staggered boards that appeared in the 1990s. Many staggered boards came from IPOs, where shareholder approval was not necessary (for example, OfficeMax, Bed Bath \& Beyond, Adobe). 155 Many others came from spin-offs, a type of IPO where market discipline is weakened by the fact that the pre-IPO "owner" is itself a public company (for example, Aviall, spun off from Ryder).156 Finally, many others in the sample came from mergers, in which the surviving company adopted the staggered board in conjunction with the merger (for example, MCA, Morgan Stanley/Dean Witter, Alumax). In these deals, the staggered board vote is bundled with the merger vote, and shareholders do not have the ability to vote in favor of the deal without also approving the staggered board.

\section{B. Assessing the Degree of Shareholder Consent}

The analysis in the previous Part suggests that shareholders in companies that adopted ESBs before 1990 - which is the vast majority of ESB companies today-could not have reasonably contemplated when the ESBs were adopted that subsequent legal developments would make them such a strong antitakeover device. Indeed, although such predictions are inherently speculative, we believe that if these shareholders had been asked to ratify the ESBs of their companies after 1990, when the antitakeover significance of ESBs became known, they would have most likely refused to do so.

The reason for this prediction is that, as documented in Part II.D, midstream companies have been largely unable to obtain shareholder approval for staggered boards since 1990. In fact, quite the opposite, institutional investors have been increasingly proposing, and shareholders have been increasingly voting for, precatory resolutions calling for destaggering the board. This evidence suggests that shareholders of companies that adopted ESBs pre-1990 would generally vote against having staggered boards if the issue were presented to them post-Time.

It might be argued that the preferences of the shareholders of companies with pre-1990 ESBs can be inferred not from their opposition to midstream adoption of staggered boards in the 1990s, but rather from the fact that many shareholders continue to buy shares in companies that went public in the 1990s with a staggered board. One of us, in other work, documents the

154. See supra text accompanying notes 68-73.

155. See Coates, supra note 2 (documenting the increase in staggered boards among IPO companies).

156. See Daines \& Klausner, supra note 2. 
growing trend in staggered board incidence in IPO companies during the 1990s. 157 However, in the case of these 1990s IPOs, the IPO price might have at least partly reflected the presence of strong antitakeover defenses, and the IPO price thus might have at least partly compensated public shareholders for the adverse effects of an ESB on their interests. ${ }^{158}$ In the case of pre-1990 ESBs, shareholders presumably could not have been compensated at the time the ESBs were adopted for the current, then unanticipated, antitakeover significance of the ESB-pill combination.

Thus, if shareholders of companies that adopted ESBs prior to 1990 were asked post-1990 to ratify the antitakeover use of their ESB, the choices that they would have been confronted with would have been most similar to those of shareholders that would have been asked in the 1990s to approve amending the charter to establish an ESB. This comparison, if correct, strongly suggests that shareholders of most ESB companies today have never given genuine consent to the powerful antitakeover device currently provided by ESBs-and would not have given such consent if provided an opportunity to express their views on the matter.

To summarize, in the vast majority of companies that have staggered boards today, the presence of strong antitakeover protections cannot be grounded in genuine shareholder consent. Rather, it is largely the unintended consequence of two unrelated sets of events: uninformed approval of staggered boards by shareholders when staggered boards had little impact on hostile bids, and a series of fact-specific court decisions that increasingly channeled hostile bids into the ballot box route. For lawmakers, this state of affairs should seem unsatisfying, to say the least. This concern, however, would be addressed by the approach to takeover law that we put forward in the next Part.

157. See Coates, supra note 2 , at 1353, 1376; sources cited supra note 2.

158. Of course, a question remains as to why pre-IPO owners have chosen in the 1990s to include ESBs in IPO charters. One of us, in the same work cited above, argues that law firm characteristics play a key role in determining the antitakeover provisions that are installed at the IPO stage. See Coates, supra note 2, at 1370-75. Another possible (not mutually exclusive) explanation is that takeover defenses may not be adequately priced in the secondary market. See Lucian Bebchuk, Freedom of Contract and the Corporation: An Essay on the Mandatory Role of Corporate Law, Discussion Paper No. 46, Program in Law and Economics, Harvard Law School (1988); Daines \& Klausner, supra note 2. Yet another explanatory factor is that, when private benefits of control are correlated with firm value and firm value is better known to owners than to public investors, owners will have incentives to choose excessive levels of protection for private benefits in order to avoid an inference by public investors that their firm is of low value. See Lucian Bebchuk, Asymmetric Information and Corporate Governance (2002) (unpublished manuscript, on file with authors). An analysis of the imperfections of the IPO process is, of course, beyond the scope of the current project. 


\section{IMPLICATIONS FOR TAKEOVER LAW}

In view of the powerful antitakeover impact and negative wealth effects of ESBs, and the common absence of genuine shareholder approval for these arrangements, we now turn to discuss how takeover law should approach them. We focus on the corporate law of Delaware, the most important law domicile for U.S. corporations, and on solutions that can be implemented taking as given the existing structure of Delaware case law. In Part VI.A we describe our recommended approach in the absence of a genuine opt-out by shareholders. We then address the question of whether shareholders should be allowed to opt-out of such a regime.

\section{A. Redeeming Pills Following Defeat in One Election}

The basic approach we propose can be stated simply: Courts should not allow managers to continue blocking a takeover bid after they lose one election conducted over an acquisition offer. Note that without an ESB, no court intervention is necessary in order to achieve this outcome. If managers of a non-ESB target are defeated in one election, the bidder will gain control of the board and will be able to redeem the pill and consummate the bid. However, with an ESB, in the absence of a court order to redeem the pill, incumbents will be able to retain independence even after losing one election over one third of the directors. Under our proposal, after the loss of one election that is effectively a referendum on the offer, incumbents should be required to redeem the pill and allow the bidder (whose offer has received shareholder support) to proceed with its bid.

Compared to other ways of reducing the power of ESBs that we have considered, our recommended approach has several advantages. First, our approach sits well with the basic principles of existing Delaware case law. In fact, we argue that our approach is called for by these principles once the special antitakeover power of ESBs is recognized. Second, and following from the first point, our approach requires no legislative intervention and can be easily implemented by the courts. Third, our approach involves minimal disruption to the existing corporate governance regime, because it prevents ESBs from having adverse and unwarranted antitakeover effects without undermining the other, non-takeover reasons for board classification. In the remainder of this Part we discuss each of these points in turn. 


\section{Consistency with fundamental principles of Delaware case law.}

First, even if our approach represents a departure from current trends, we believe that it better reflects the fundamental principles of the Delaware case law. An important factual assumption of current takeover jurisprudence has been the existence of a ballot box safety valve against incumbents who abuse the power to maintain the pill. However, as we have shown theoretically and confirmed empirically, this assumption is incorrect in the case of targets with ESBs. Because of the illusory nature of the ballot box safety valve against ESB targets, the fundamental principles of takeover law justify (if not require) courts' intervention to order managers to redeem the pill following one proxy contest's defeat.

To see why, begin with Unocal, which allows managers to engage in defensive action only as long as they maintain balance and "proportionality" in relation to the perceived threat from the hostile bidder. ${ }^{159}$ Once it is understood that the ballot box route is hardly viable against an ESB target, maintaining a pill after a shareholder referendum in favor of the bidder can be readily construed as disproportionate to the threat posed. Thus, once the consequences of an ESB are fully recognized, our approach could be viewed as an application of the "intermediate" standard of review announced in Unocal.

Our approach is also consistent with Moran, which states that directors should not use a pill to "arbitrarily reject" an offer made by a hostile bidder. ${ }^{160}$ Refusing to concede after losing an informed shareholder referendum on a bid could fairly be considered "arbitrary," and thus within this intent. More generally, while Moran reserves for the court the right to order the redemption of the pill when appropriate circumstances arise, courts have historically declined to use this power, in large part due to their belief that the ballot box safety valve is a viable check against excessive abuse. Once it is recognized that the ballot box route may not be a viable check against disloyal directors of ESB targets, a court-ordered redemption of the pill after the loss of one proxy contest over the bid would be a sensible use of Moran's mandate.

Our approach is also consistent with Unitrin. Even though this case is known for giving especially strong support to defensive tactics, it still maintains that such tactics cannot be "preclusive" and must fall within a

159. Under Unocal, the Delaware Supreme Court outlined a two-prong analysis: First, the target board must have some basis for concluding that the hostile bid poses a threat to the company; and second, the defensive measure "must be reasonable in relation to the threat posed." Unocal, 493 A.2d at 955.

160. See Moran, 500 A.2d at 1354. 
"range of reasonableness."161 Given our finding that not a single bidder in the second half of the 1990s won two elections against incumbents protected by an ESB, 162 our proposed approach flows directly from Unitrin's requirement that a target's defensive response not "preclude" hostile bids. Our analysis suggests that, unless managers are allowed to use a pill-ESB combination to force only one election rather than two, the pill-ESB combination becomes preclusive. Our approach is also consistent with Unitrin's requirement that a target's defensive response fall within a "range of reasonableness": For a target board to continue to maintain a poison pill in place after losing an election fought over a given bid-with the full opportunity that such a vote provides for target directors to articulate why the bid is not in the interest of shareholders generally-can readily be characterized as unreasonable.

In short, by focusing on the fact that a target has already lost an initial proxy contest in the context of a given bid, our approach provides a way for Delaware courts to create boundaries on the scope of "Just Say No" in a way that is consistent with existing jurisprudence on the issue. ${ }^{163}$ It is helpful to note that our approach would not differ in terms of the actual holding, though it would differ in reasoning, from Wallace Computer. Recall that in that case a federal district court, applying Delaware corporate law, refused to order managers armed with an ESB and a pill to redeem the pill even though more than $70 \%$ of the shareholders had tendered into the offer. Although we would not be inclined (unlike the Wallace court) to allow managers to retain the pill indefinitely, our approach would not call for judicial intervention at the point at which such intervention was requested in Wallace. Under our approach attracting enough tenders would not be sufficient to require redemption of the pill - there needs to be a shareholder vote as well. ${ }^{164}$ Only after incumbents have lost an election fought over a bid should they be required to redeem the pill.

161. The second prong of the Unocal test was elaborated in Unitrin to mean that a defense could be neither preclusive nor coercive, and must otherwise fall in a "range of reasonableness." Unitrin, 651 A.2d at 1387-88.

162. See supra Part IV.B.

163. Cf. Ronald J. Gilson \& Reinier Kraakman, Delaware's Intermediate Standard for Defensive Tactics: Is There Substance to Proportionality Review?, 44 BUS. LAW. 247 (1989).

164. For the view that expression of shareholder support through a vote and not only through tender decisions is necessary for a hostile takeover, see Bebchuk, supra note 80; Bebchuk \& Hart, supra note 86. 


\section{Legislative intervention not required.}

Because our approach is consistent with the basic principles of existing jurisprudence, it could be implemented by the Delaware courts without the need for legislative intervention. We believe that this feature makes it more attainable at a practical level. In other work, two of us have independently shown that the passage of antitakeover legislation helps states attract and retain incorporations. ${ }^{165}$ To the extent that the Delaware courts are less influenced by the desire to attract incorporations than are state legislatures, courts may be more likely to take steps that, although highly warranted, would have the effect of reducing the level of protection from takeovers.

In addition to this practical benefit, a judicial solution would also have a substantive benefit over a legislative approach. A legislative solution would most likely involve the elimination of SBs from the menu of options. As discussed in Part II.C.1, however, there may be legitimate, non-takeover related reasons to have SBs. A judicial approach would preserve these benefits by requiring redemption of the pill only after the incumbent board has lost one election to a hostile bidder. Outside the context of a hostile takeover, SBs would continue to function as they do at present. Therefore, a judicial solution would address the problems we have identified in a more targeted way than a legislative solution.

\section{Substantial consequences with minimal disruption.}

At first sight, this targeted solution may seem so minimalist as to have limited practical significance. After all, only one hostile bidder in our sample period, and to the best of our knowledge only five hostile bidders ever, have won a first proxy contest conducted over their bid against an ESB: Moore against Wallace Computer, Carson Pirie Scott against Younkers, U.S. Surgical against Circon; Boston Bank of Commerce against Carver Bancorp; and Weyerhaeuser against Willamette. ${ }^{166}$ Among these five bids, one was eventually sold to the initial bidder (Willamette), two were sold to another bidder within a few months after the hostile bidder withdrew (Circon and Younkers), and two (Wallace Computer and Carver Bancorp) remained independent after losing a first proxy contest. Therefore, it might be argued that our approach would have practical significance for only a small number of cases.

However, this argument misses the point that all the actions of bidders

165. See sources cited supra note 30

166. Circon occurred during the period we study, Wallace Computer and Younkers occurred before it, and Willamette and Carver Bancorp occurred since the end of this period. 
and targets in all takeover contests occur against the background of the ultimate powers and threats available to the parties. With a non-ESB target, the viability of the ballot box route influences outcomes not only in those cases in which the bidder actually wins a ballot box victory but also in those cases in which incumbents proceed to a negotiated sale because they know that they would not be able to block an offer that would enjoy shareholder support. Similarly, with an ESB target, the outcome is not only affected in the few instances in which the bidder wins the first election and then gives up. It is also affected in the larger number of cases in which bidders give up earlier against an ESB knowing how difficult and costly a ballot box victory would have to be.

In our sample, the "shadow of the law" has influenced the outcome of hostile bids against all forty-five ESB targets. ${ }^{167}$ In particular, it has allowed twenty-seven of those targets to remain independent in the short run and twenty-one to remain independent in the longer-term-a much larger fraction than in the case of non-ESB targets. Thus, while our approach would call for judicial intervention only when a bidder wins a proxy contest, it would influence the outcomes of bids against all ESB targets.

In effect, our approach would convert ESB targets into EAT targets for takeover purposes - targets for which the board could be fully ousted but only at the next annual meeting. By doing so, our approach would revitalize the ballot box safety valve against ESB targets. This safety valve would ensure that managers are unable to pursue a course of action that does not ultimately have shareholder support. Our approach targets precisely the antitakeover feature of ESBs while leaving intact other features of SBs that may be desirable for non-takeover-related reasons. ${ }^{168}$ Thus our proposal is both significant (by influencing the "shadow" negotiation that occurs in every hostile bid contest) and minimally disruptive (by preserving existing board structures and allowing staggered boards when they are justified by other business considerations).

\section{B. The Permissibility of Opt-Out}

The question arises, as is often the case in corporate law policy discussions, whether and to what extent opting out should be allowed. Should companies be permitted to opt out of our approach by adopting a charter provision that explicitly authorizes boards to maintain a pill even when they lose one proxy contest fought over an acquisition offer?

The question of contractual freedom has been extensively debated

167. Cf. Mnookin \& Kornhauser, supra note 129.

168. See supra Part II.C.1. 
elsewhere ${ }^{169}$ and is beyond the scope of our project. For those who believe in completely unfettered contractual freedom, the answer is necessarily that companies should be allowed to opt into any arrangement that receives shareholder approval. This is not our view, nor has it been the view of corporate law in general or of takeover jurisprudence in particular. Corporate law does not offer companies an unlimited choice. Rather, it offers a certain menu of options from which companies may choose. ${ }^{170}$ Thus, the question is whether the arrangement currently offered by an ESB-poison pill combination is one that should be part of the menu from which companies may choose.

Our analysis suggests that the ESB antitakeover device is one that might not be worth including in a limited optimal menu of choices-even if one wants to include in this menu some options that provide managers with a greater veto power than an EAT provides. We say "if" because the question of board veto power is one on which there are different views. ${ }^{171}$ However, even someone who wishes to include in the menu options that provide greater, even far greater, veto power than provided by an EAT would be well advised to do it through arrangements other than the two-election staggered board device.

One way to expand veto power would be to expand the duration of terms to which directors may be elected - an arrangement allowing directors to be elected for a period of $X$ years, where $X$ is greater than one, the current maximum level. Another way to expand veto power would be to enable votes on the election of directors to take place only after $\mathrm{Y}$ months have elapsed since the making of the bid. The first type of arrangement would provide directors with a certain guaranteed time after they are elected. The second type of arrangement would provide directors with a certain guaranteed period of $\mathrm{Y}$ months after a bid is made to prepare and

169. For an overview of the debate, see Lucian Arye Bebchuk, The Debate on Contractual Freedom in Corporate Law, 89 ColuM. L. REV. 1395, 1395-1415 (1989). Some reasons for constraining contractual freedom in the context of takeover arrangements are given in Lucian Arye Bebchuk, Limiting Contractual Freedom in Corporate Law: The Desirable Constraints on Charter Amendments, 102 HARV. L. REV. 1820 (1989); Bebchuk, supra note 158. For a recent work casting some empirical doubt on the optimality of antitakeover arrangements adopted at the IPO stage, see Coates, supra note 2, at 1301.

170. To take just one of many examples, companies may choose whether shareholders can act before the annual election or only at the annual election, but companies must hold an election every year and may not opt-out from this requirement. Similarly, companies may have elections each year for fewer than all of the directors, but most states limit the number of classes in which the board may be staggered. See supra text accompanying notes 10-13.

171. For a survey and critique of the arguments for board veto power, see Bebchuk, supra note 80 . 
communicate alternatives to shareholders. But both arrangements, however much time they provide, would enable a hostile bidder to have at some point a one-time, up-or-down referendum on its acquisition offer.

In contrast, such a one-time, up-or-down referendum on acquisition offers is never possible, as we have shown, under the current ESB arrangement. While reasons can be given for providing mangers with a certain amount of guaranteed time under one of the two types of arrangements above, there is, in our view, no good reason to prevent bidders from ever getting a one-time referendum on an offer. Even if providing incumbents with greater veto power is desired, there are better ways to do so than through the frictional, ill-functioning arrangement of two votes, one year apart. For this reason, the menu of offered options should not include an arrangement under which a hostile bidder would have to win two elections, one year apart, in order to gain control.

\section{CONCLUSION}

Effective staggered boards are the most powerful antitakeover device in the current arsenal of takeover defense weapons. An ESB prevents a hostile bidder, no matter when it emerges, from gaining control of the target unless it can wait at least fourteen months and win two elections that are far apart in time. Because of these impediments, the ballot box route becomes illusory against an ESB target.

We find strong empirical support for this view of ESBs. ESBs substantially increase the likelihood that a target receiving a hostile bid will remain independent. We find that the increased odds of remaining independent are quite costly for target shareholders, without providing sufficient countervailing benefits in terms of higher acquisition premiums. We estimate that an ESB reduces the expected return of target shareholders in the nine months after a hostile bid is launched on the order of $8-10 \%$. The negative wealth effect associated with ESBs is particularly problematic from a policy perspective because the majority of staggered boards were established before the judicial developments that gave them their antitakeover potency.

We put forward an approach that courts could follow to address these problems. Specifically, we propose that target managers should not be permitted to maintain a pill after losing a first proxy contest against a hostile bidder. Although our proposal seems to go against the current trend in Delaware case law that is solidifying and expanding the "Just Say No" defense, it would in fact best serve the principles and concerns underlying proportionality review under Unocal. Essentially, our proposal would revitalize the ballot box route, which the Delaware courts have relied on so 
heavily in developing takeover jurisprudence, but whose existence is currently illusory for companies with ESBs.

Our approach would eliminate the entrenching effects of ESBs by addressing both the minimum delay problem and the two-election problem. Furthermore, our approach could be implemented easily by courts, without requiring legislative change or forgoing the non-antitakeover benefits that staggered boards might provide. This approach could, with little cost and judicial intervention, contribute significantly to shareholder welfare and to a healthier and more efficient acquisition market. 